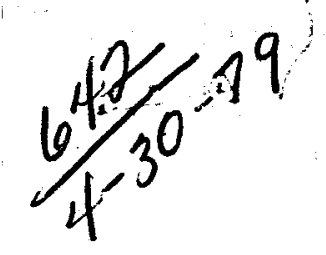

th. 2501

TREE-1340

\title{
1978 ANNUAL REPORT, INEL GEOTHERMAL ENVIRONMENTAL PROGRAM
}

\author{
SUSAN G. SPENCER JACQUELYN F. SULLIVAN
}

NORMAN E. STANLEY

APRIL 1979

EG\&G Idaho, Inc.

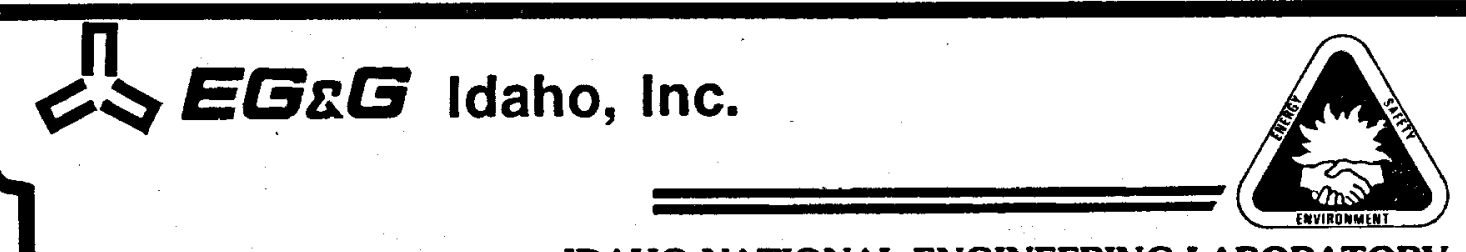

IDAHO NATIONAL ENGINEERING LABORATORY

\section{DEPARTMENT OF ENERGY}

IDAHO OPERATIONS OFFICE UNDER CONTRACT EY-76-C-07-1570

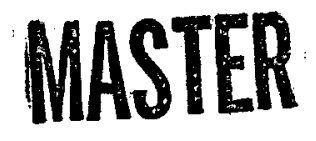




\section{DISCLAIMER}

This report was prepared as an account of work sponsored by an agency of the United States Government. Neither the United States Government nor any agency Thereof, nor any of their employees, makes any warranty, express or implied, or assumes any legal liability or responsibility for the accuracy, completeness, or usefulness of any information, apparatus, product, or process disclosed, or represents that its use would not infringe privately owned rights. Reference herein to any specific commercial product, process, or service by trade name, trademark, manufacturer, or otherwise does not necessarily constitute or imply its endorsement, recommendation, or favoring by the United States Government or any agency thereof. The views and opinions of authors expressed herein do not necessarily state or reflect those of the United States Government or any agency thereof. 


\section{DISCLAIMER}

Portions of this document may be illegible in electronic image products. Images are produced from the best available original document. 
Printed in the United States of America Available from

National Technical Information Service U.S. Department of Commerce 5285 Port Royal Road Springfield, Virginia 22161

Price: Printed Copy \$5.25; Microfiche $\$ 3.00$

\section{NOTICE}

This report was prepared as an account of work sponsored by the United States Government. Neither the United States nor the Department of Energy, nor any of their employees, nor any of their contractors, subcontractors, or their employees, makes any warranty, express or implied, or assumes any legal liability or responsibility for the accuracy, completeness or usefulness of any information, apparatus, product or process disclosed, or represents that its use would not infringe privately owned rights. 
TREE-1340

1978 ANNUAL REPORT,

INEL GEOTHERMAL ENVIRONMENTAL PROGRAM

by

S. G. Spencer 9

J. F. Sullivan $g \neq d$

N. E. Stantey $/ 25$

This report was prepared as an account of work

sponsored by the United States Government. Neither the

United States nor the United States Department of

Energy, nor any of their employees, nor any of their

contractors, subcontractors, or their employees, makes

any warranty, express or implied, or assumes any legal

liability or responsibility for the accuracy, completenets

or usefulness of any information, apparatus, product of

process disclosed, or represents that its uxe would not

infringe privately owned rights.

APPROVED:

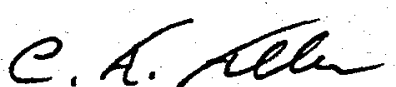

C. A. Allen, Branch Manager Biological \& Earth Sciences

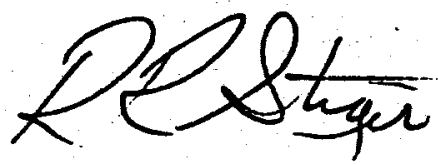

R. R. Stiger, Manager Advanced Programs 


\section{INEL GEOTHERMAL ENVIRONMENTAL PROGRAM}

S. G. Spencer

J. F. Sullivan

N. E. Stanley

EG\&G Idaho, Inc.

Idaho Falls, Idaho 83401

Published April 1979

PREPARED FOR THE

U.S. DEPARTMENT OF ENERGY

IDAHO OPERATIONS OFFICE

UNDER CONTRACT NO. EY-76-C-07-1570 


\section{ACKNOWLEDGMENTS}

During the past four years of the Geothermal Environmental Program, several individuals and agencies have provided much appreciated technical advice and support. For this support, we owe a special thanks to E. G. Crosthwaite, U.S. Geological Survey; Rich Howard, U.S. Fish and Wildlife Service; Jim Pribble and Nick Cozakos, Burley District, Bureau of Land Management; and the staff of the Idaho Department of Water Resources. 


\begin{abstract}
The objective of the Raft River Geothermal Environmental Program, in its fifth year, is to characterize the beneficial and detrimental impacts resulting from the development of moderate-temperature geothermal resources in the valley. This report summarizes the monitoring and research efforts conducted as part of this program in 1978. The results of these monitoring programs will be used to determine the mitigation efforts required to reduce long-term impacts resulting from geothermal development.
\end{abstract}




\section{CONTENTS}

ACKNOWLEDGMENTS $\ldots \ldots \ldots \ldots \ldots \ldots \ldots \ldots$ ii

ABSTRACT $\ldots \ldots \ldots \ldots \ldots \ldots \ldots \ldots \ldots \ldots \ldots \ldots \ldots \ldots \ldots$ iii

I. INTRODUCTION $\ldots \ldots \ldots \ldots \ldots \ldots \ldots \ldots \ldots$

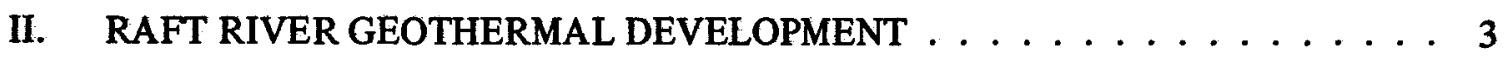

III. PHYSICAL ENVIRONMENT MONITORING PROGRAMS $\ldots \ldots \ldots \ldots$

1. AIR QUALITY $\ldots \ldots \ldots \ldots \ldots \ldots \ldots \ldots \ldots$

2. METEOROLOGY .................... 10

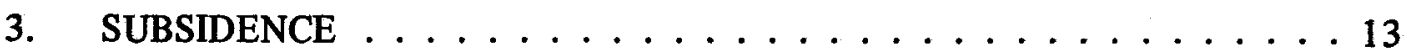

4. WATER QUALITY $\ldots \ldots \ldots \ldots \ldots \ldots \ldots \ldots$

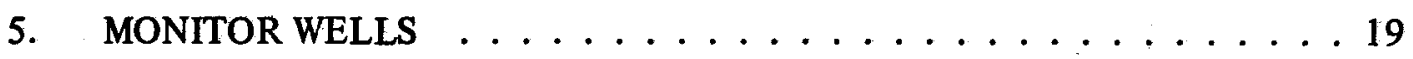

IV. BIOLOGICAL ENVIRONMENT MONITORING PROGRAMS $\ldots \ldots . \ldots 27$

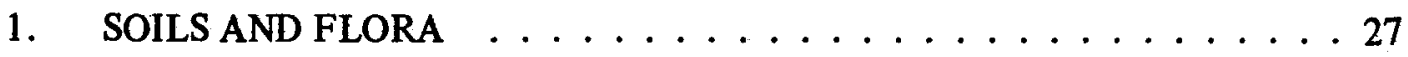

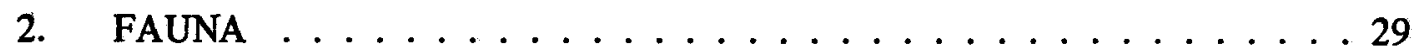

2.1 Small Mammals $\ldots \ldots \ldots \ldots \ldots \ldots \ldots \ldots \ldots \ldots \ldots \ldots$

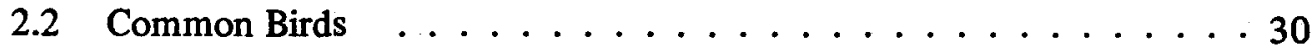

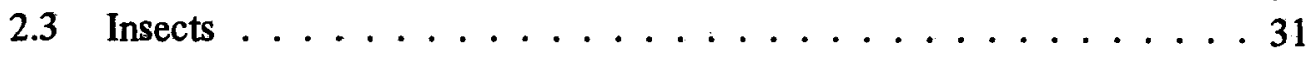

3. RAPTOR DISTURBANCE RESEARCH $\ldots \ldots \ldots \ldots \ldots$

V. HUMAN AND CULTURAL MONITORING PROGRAMS $\ldots \ldots \ldots$

VI. SNAKE RIVER BASIN PROGRAM . . . . . . . . . . . . . . . . 39

VII. RELATED PROGRAMS $\ldots \ldots \ldots \ldots \ldots \ldots \ldots \ldots$

VIII. REFERENCES $\ldots \ldots \ldots \ldots \ldots \ldots \ldots \ldots \ldots \ldots \ldots \ldots \ldots \ldots$

APPENDIX - RAFT RIVER ENVIRONMENTAL INFORMATION

REPORTS . . . . . . . . . . . . . . . . . . . . . . 49 


\section{FIGURES}

1. Location of Raft River geothermal site . . . . . . . . . . . . . . 4

2. Raft River geothermal site .................... 5

3. Raft River geothermal well schematic . . . . . . . . . . . . . 6

4. Electron micrographs of particles from RRGE-3 water

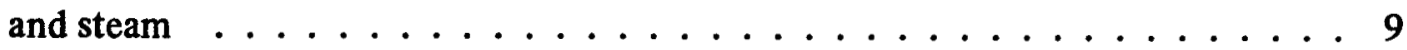

5. Raft River 1977 wind rose ..................... 11

6. Raft River 1977 temperature ..................... 12

7. Raft River 1977 precipitation ..................... 13

8. Water chemistry surveys of selected irrigation wells ............ 18

9. Raft River geothermal and monitor wells ................. 21

10. Construction and lithology of monitor wells . . . . . . . . . . . . . 22

11. Temperature profiles of monitor wells ... . . . . . . . . . . 23

12. Monitor well response during RRGI-4 injection test . . . . . . . . . . . 25

13. Record of USGS-3 wellhead pressure . . . . . . . . . . . . 26

14. Map of vegetation and permanent plots ............... 28

15. Juvenile ferruginous hawk (Buteo regalis) . . . . . . . . . . . 32

16. Location of ferruginous hawk nests ................. 33

17. Teeth of selected fluorosis study subjects ................ 37

18. Locations of known geothermal resource areas in

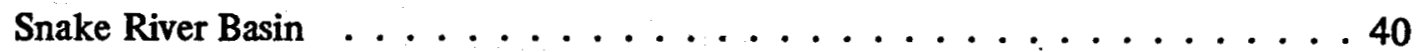

19. Simulated environment for resource use exercise ............. 43 


\section{TABLES}

I. Program Highlights and Future Plans $\ldots \ldots \ldots \ldots \ldots$

II. Particulate Concentration in Raft River, $1978\left(\mu \mathrm{g} / \mathrm{m}^{3}\right) \ldots \ldots \ldots \ldots$

III. Particulates Collected in Plume From RRGE-2 $\ldots \ldots \ldots \ldots \ldots$

IV. Water Quality - Raft River Water Sources (Raft River

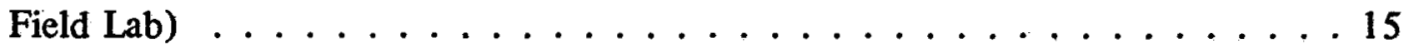

V. Chemical Analyses of Raft River Geothermal Water (Mean Value

of Available Data - In mg/l Unless Otherwise Noted) . . . . . . . . . 16

VI. Water Quality - Irrigation Well 14S 27E 32bddl (In mg/l

Unless Otherwise Noted) . . . . . . . . . . . . . . . . . . . 19

VII. Initial Water Quality - Monitor Wells (Mean Value of

Available Data - In $\mathrm{mg} / 1$ Unless Otherwise Noted) . . . . . . . . . . . . . 24

VIII. Type of Impact and Results at Treatment Nests . . . . . . . . . . . 34

IX. Fledging Rates for 1978 Season $\ldots \ldots \ldots \ldots$. . . . . . . . 35

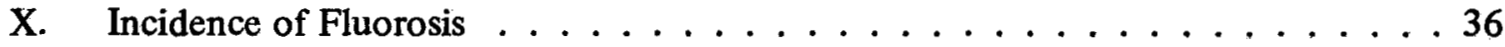




\section{ANNUAL REPORT,}

\section{INEL GEOTHERMAL ENVIRONMENTAL PROGRAM}

\section{INTRODUCTION}

The geothermal environmental program began in 1974 with baseline studies and environmental assessments of exploratory well drilling in the Raft River Valley. Baseline studies included the characterization of flora and fauna, surface and groundwater quality, heritage resources, air quality, socioeconomics, seismic activity, soil type and chemistry, meteorology, geology, and the documentation of historic subsidence. The results of these studies are summarized in the Environmental Report, Raft River Thermal Loop Facility ${ }^{[1]}$. Individual environmental data reports are listed in the appendix to this annual report.

As a result of the baseline studies and evaluations of initial geothermal development in the area, the two primary environmental concerns identified were: (a) impacts on the ferruginous hawk, a sensitive species nesting abundantly in the valley; and (b) impacts on the quality and supply of surface and groundwater resources in the basin. In addition, relatively high fluoride levels in local domestic and irrigation water supplies were identified as a "public" concern. Monitoring programs were established for each component of the environment included in the baseline studies, with particular emphasis placed on the major areas of concern.

This report is the first of a series on the progress, results, and conclusions of these monitoring programs and research efforts. A brief summary of the Snake River Basin Environmental Program is also included. Funding for these programs comes from the Department of Energy's Division of Geothermal Energy and Office of Health and Environmental Research (formerly Division of Biomedical and Environmental Research). Program highlights are shown in Table I. 


\section{TABLE I}

PROGRAM HIGHLIGHTS AND FUTURE PLANS

Environmental Activities

Environmental program initiated with baseline characterization studies (May 1974)

Major baseline studies completed (December 1976)

Raft River Therma] Loop Environmental Report issued (June 1977)

Monitor wells drilled (November 1977)

Injection monitoring initiated

(March 1978)

Snake River Basin program funded (March 1978)

Ferruginous hawk research initiated (May 1978)

Snake River Basin report issued (June 1979)

Raft River Injection Monitoring report issued (September 1979)

Final Raft River Environmental Evaluation completed (August 1983)
Geothermal Activities

Geothermal program initiated (1973)

RRGI-4 drilled (May 1977)

Prototype binary power plant operational (April 1978)

RRGI-6 drilled (May 1978)

RRGP-5 drilled (July 1978)

RRGI-7 drilled (August 1978)

Construction begun on 5-MW power plant (August 1978)

5-MW plant operational (October 1980) 


\section{RAFT RIVER GEOTHERMAL DEVELOPMENT}

The Geothermal Program at the Idaho National Engineering Laboratory (INEL) was initiated in 1973 with geological and geophysical exploration. A cooperative agreement between the U.S. Department of Energy (DOE), the state of Idaho, and the Raft River Rural Electric Cooperative was signed to provide support for the program. DOE took the lead role in the program, which was designed to demonstrate that moderate-temperature geothermal fluids could be used to generate electricity and to provide an alternative energy source for direct applications.

Two shallow irrigation wells in southern Idaho's Raft River valley produce fluids of $100^{\circ} \mathrm{C}$, suggesting a geothermal resource (Figure 1). The first geothermal exploratory well (RRGE-1) was located near these two wells, and it was designed to intersect major faults at depth. This well, drilled in early 1975 , encountered a $150^{\circ} \mathrm{C}$ resource at a depth of $1400 \mathrm{~m}$. Since then, six more wells have been drilled (Figures 2 and 3). RRGE-2 and RRGP-5 were located along the Bridge fault structure and will be used with RRGE-1 as production wells. RRGE-3 was drilled out in the basin and was designed with three "legs" below the casing to increase production. This well will be used as a production well. Well RRGI-4 was initially drilled as an injection well to determine the feasibility of intermediate-depth injection. Following injection tests in early 1978, the well was deepended for use as a production well. Currently the temperature and production from RRGI-4 are low, and its status is under review. RRGI-6 and RRGI-7 were drilled as intermediate-depth injection wells and were located to reduce the potential for interaction of cold injected fluids with the main resource.

Experiments currently operating at the site include an aquaculture facility, a fluidized-bed dryer, and a geothermal heating and cooling system. The use of a soil-cooling system as a replacement for a cooling tower is being tested in conjunction with several agricultural experiments. A prototype binary power plant went into operation in early 1978. This plant is being used to simulate various operating environments for testing equipment, designs, processes and materials for more advanced power-plant facilities.

Construction of a 5-MW(e) binary power plant was begun in late 1978. The plant will use isobutane as a secondary fluid in a closed-cycle system; under normal plant operating conditions, no geothermal fluids will be exposed to the atmosphere. Effluent from the power plant will be either injected or utilized in direct-use applications. Start-up of the 5-MW power plant is schedule for 1980 . Following a period of three years, during which the performance of the facility will be tested, it is scheduled to be transferred to a utility for operation. 


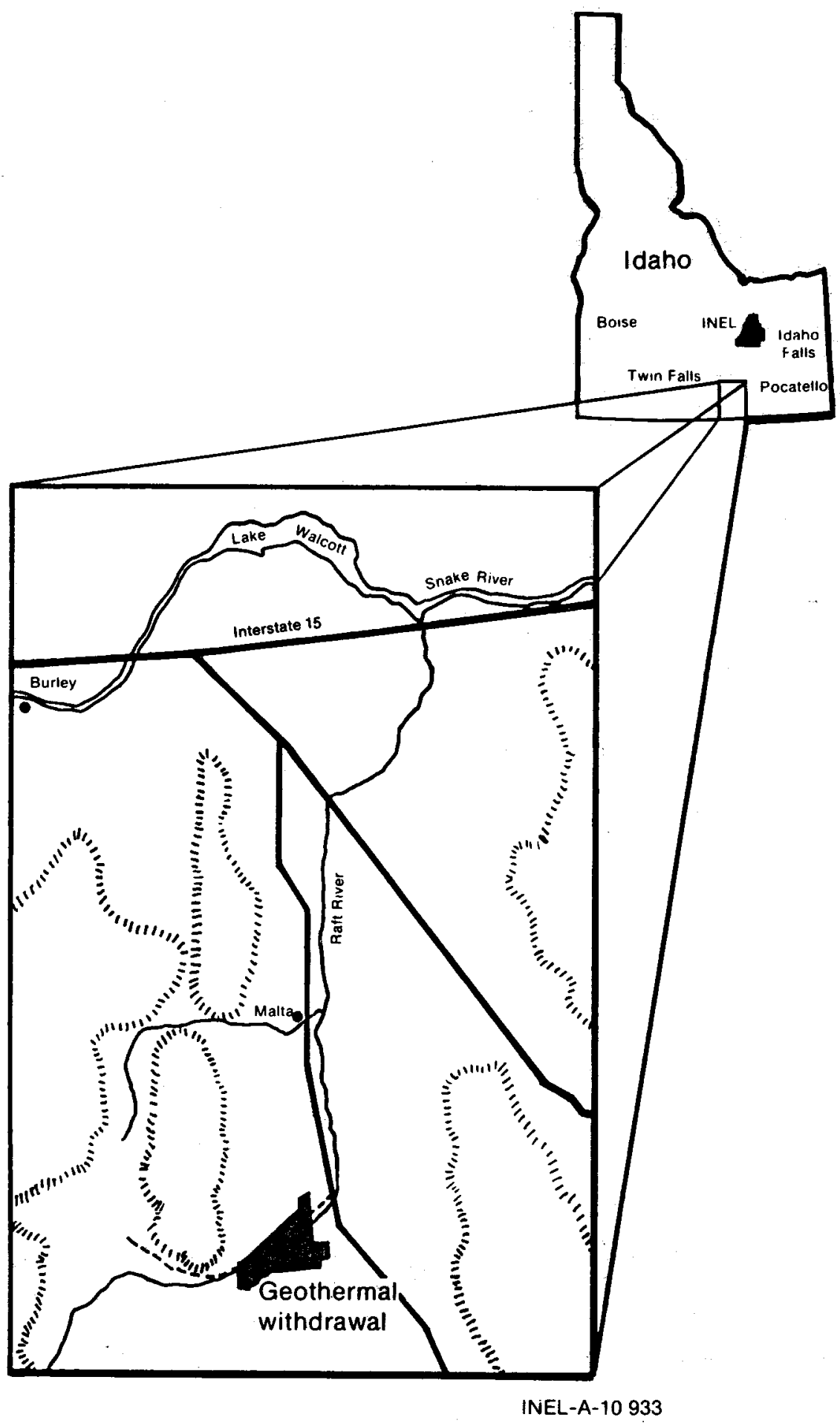

Fig. 1 Location of Raft River geothermal site. 


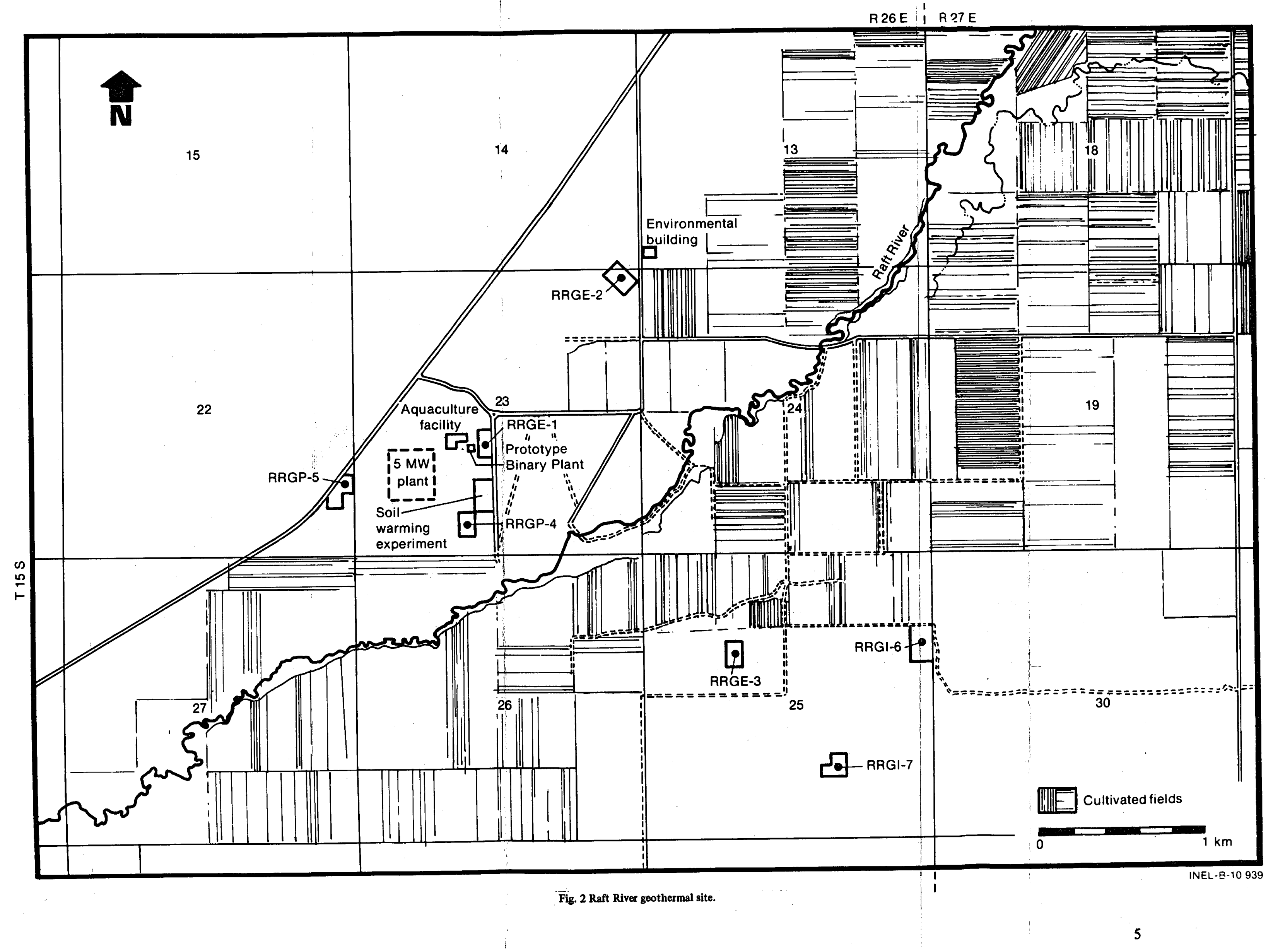


$a$

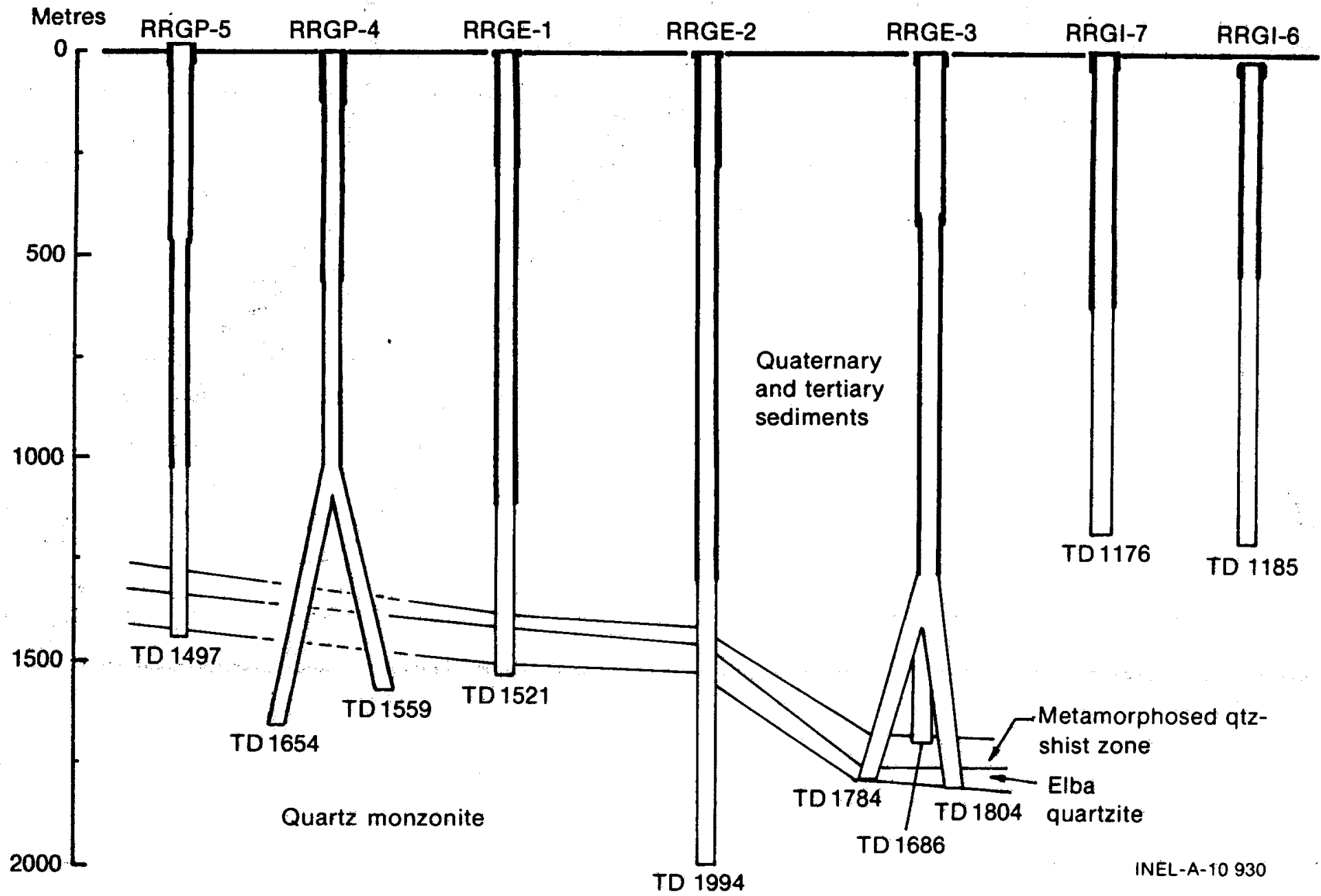

Fig. 3 Raft River geothermal well schematic. 


\section{PHYSICAL ENVIRONMENT MONITORING PROGRAMS}

\section{AIR QUALITY}

When geothermal development began in the Raft River valley, the primary air quality concern was anticipated to be the emission of hydrogen sulfide, based on experience at the Geysers in California: As a result, baseline air-quality studies were initiated in Raft River in 1975. These studies identified a significant influx of pollutants, primarily sulfates, from the Wasatch Front to the south.

The Raft River geothermal fluids contain only very small amounts of noncondensable gases. Because of this, air pollution resulting from development in the valley is not expected to be a major problem. Air-quality monitoring will continue, however, to determine if this assessment is accurate.

Two permanent particulate sampling stations were installed during 1978: one east of RRGE-2 and one at Naf, $13 \mathrm{~km}$ southeast of the test site. Hi-Vol sampling began on April 21, 1978, at the RRGE-2 station, which is downwind from the 5-MW power plant site. The Naf station was established to monitor particulates entering the valley from the Wasatch Front. Hi-Vol sampling began here on September 6, 1978. Nuclepore filters are used at each station to obtain information on particle types, concentrations, and size distributions. These filters have not yet been processed through the scanning electron microscope.

Total suspended particulate concentrations have been computed for the six-month period from April through September. The geometric mean concentrations for each month are shown in Table II, with corresponding baseline values shown in parentheses.

The majority of particulates collected were classified as soil dust, based on visual observation. Geothermal development can be expected to increase the ambient levels of soil dust as a result of clearing, construction activities, and substantially increased traffic on

TABLE II

PARTICULATE CONCENTRATION IN RAFT RIVER, 1978 $\left(\mu \mathrm{g} / \mathrm{m}^{3}\right)$

\begin{tabular}{|c|c|c|c|c|c|c|}
\hline & April & May & June & July & August & September \\
\hline RRGE-2 & 30 & $28(51)$ & $70(36)$ & $81(48)$ & $73(29)$ & $70(25)$ \\
\hline Naf & -- & -- & -- & -- & -- & 25 \\
\hline \multicolumn{7}{|c|}{ ( ) baseline values } \\
\hline
\end{tabular}


unpaved roadways. The RRGE- 2 station is located next to one of two access roads to the main development area, and this is reflected in the values shown. Increased activity due to construction of the power plant and well drilling and testing during the dry summer months also contribute to the increased levels of particulates. As revegetation of disturbed areas is completed and roads are upgraded, the local particulate levels are expected to decrease.

The power plant will operate on a closed-cycle basis; however, geothermal fluids may be used as make-up for the cooling tower. If this is the case, cooling-tower drift could be a source of particulates in the area. Particulates were collected in a plume at RRGE-2 during a 1976 flow test, and particles were generated from RRGE-2 and RRGE-3 water samples to characterize what might be expected from the cooling tower. The distribution of particles from the plume study are displayed in Table III. Energy-dispersive $\mathrm{x}$-ray analysis showed that these particles were not sodium chloride, as was expected (indicating that the liquid droplets containing salt were not collected).

TABLE III

PARTICULATES COLLECTED IN PLUME FROM RRGE-2

\begin{tabular}{ccl}
$\begin{array}{c}\text { Size } \\
\text { (Microns) }\end{array}$ & $\begin{array}{c}\text { Percentage of } \\
\text { Total Number }\end{array}$ & $\frac{\text { Elements Present }}{2}$ \\
$2-4$ & 65 & Si, Cl, Fe \\
$4-6$ & 18 & Si, Fe, K \\
$6-8$ & 10 & Si, Ca, K, Fe \\
$8-30$ & 6 & Si, Fe, Ca \\
\hline
\end{tabular}

Particles produced by a particle generator ranged in size from 1 to less than 0.2 micron. The majority of the particles were cubical (Figure 4), and only chlorine and sodium could be detected with energy-dispersive $x$-ray analysis. The concentration of the submicron particles was approximately $13 \mu \mathrm{g} / \mathrm{cc}$ of water.

Based on these results, expectations are that the power plant will release some particulates to the atmosphere under normal operating conditions. Studies will be conducted around the prototype plant's cooling tower in 1979 , to further define the type and quantity of these particulates. 


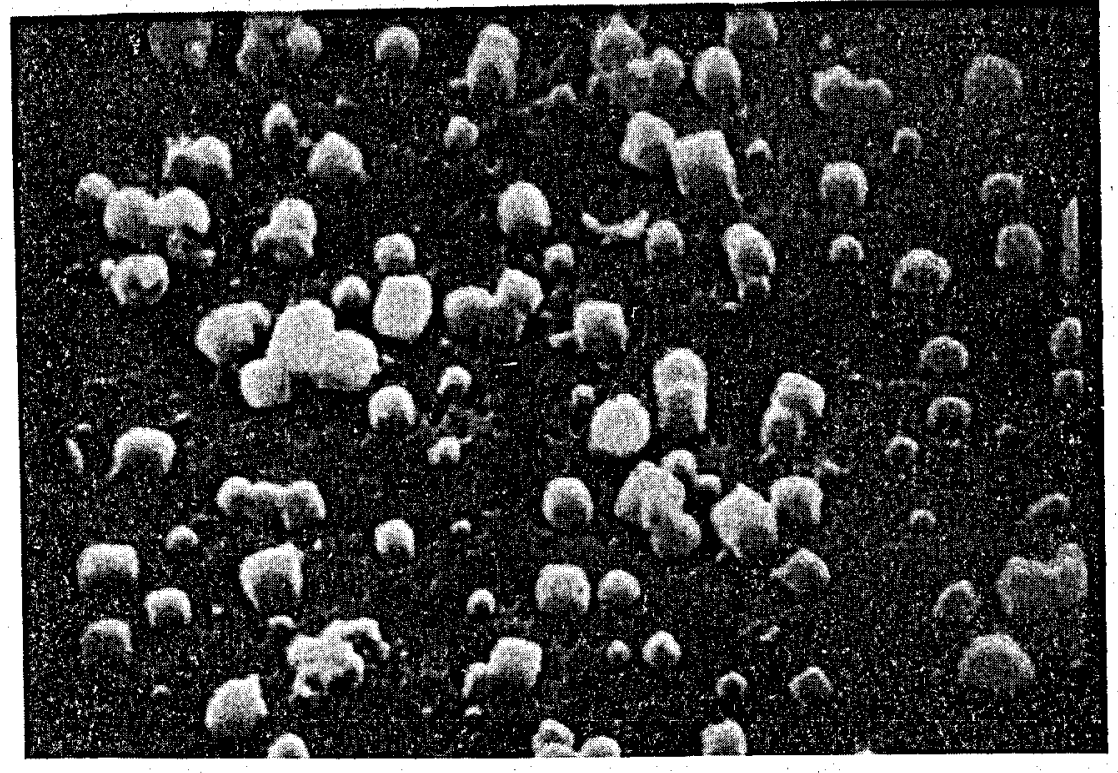

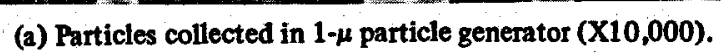

0

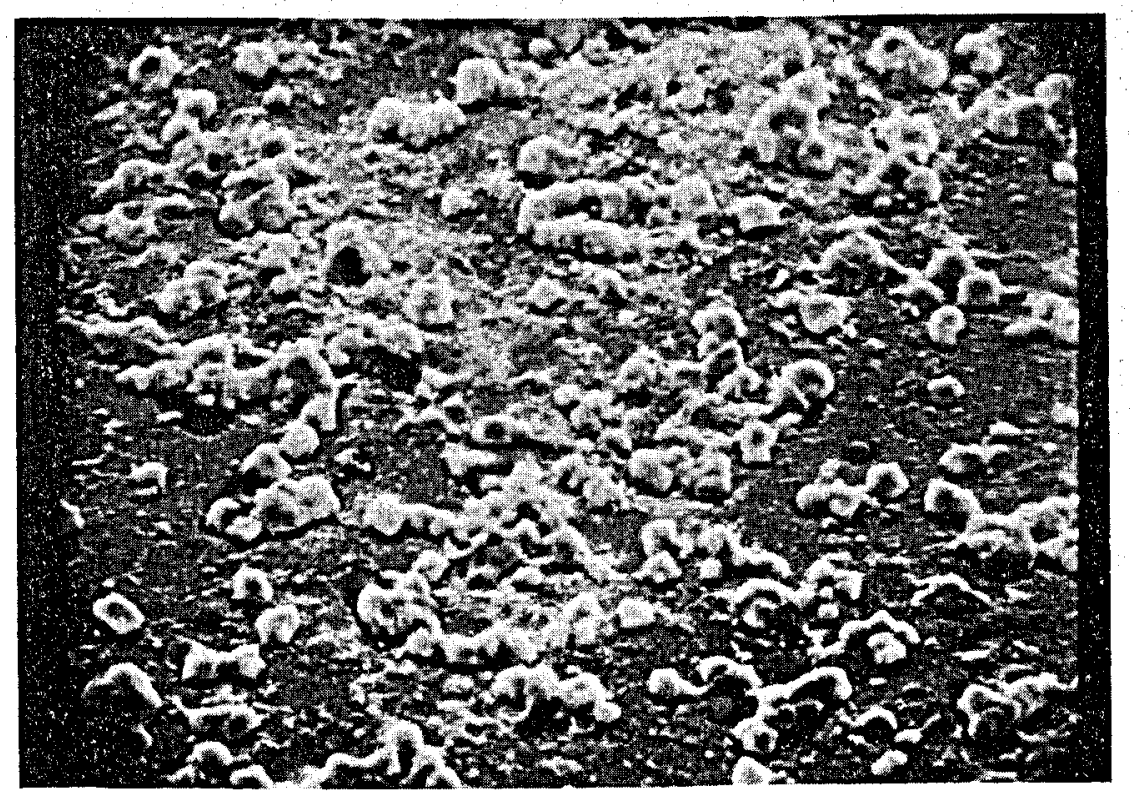

(c) Particles from evaporated water (X500).

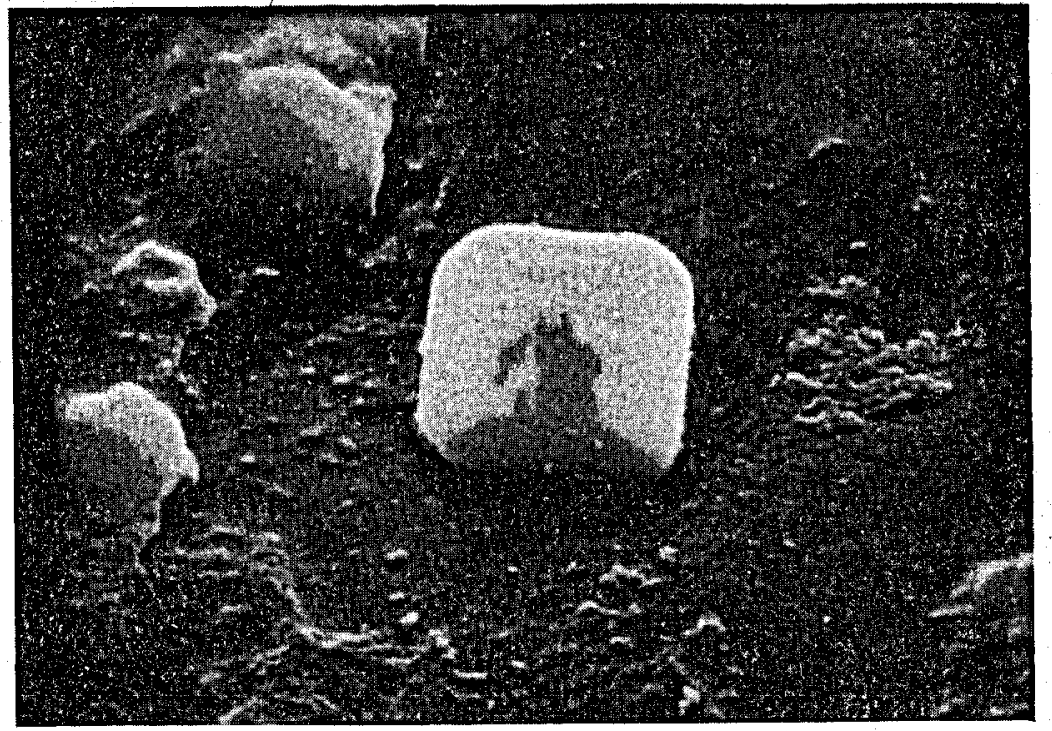

(b) Sodium chloride crystal from evaporated water (XS000).

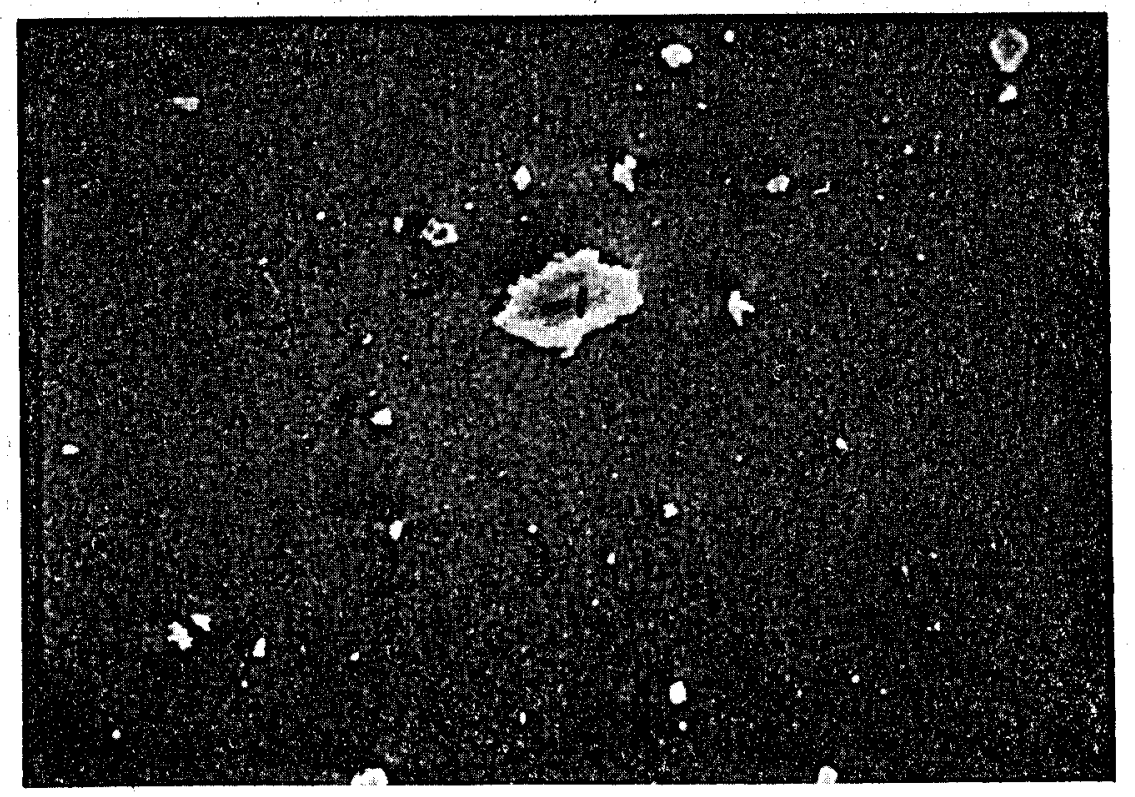

(d) Particles collected in steam plume (X500). 


\section{METEOROLOGY}

A weather station installed at the environmental building just east of the RRGE-2 well site monitors ambient temperature, dewpoint temperature, wind speed and direction, and precipitation. This information is used as design input for various experiments and the 5-MW power plant and will provide input for determining plant operating efficiencies. The monitor inputs are sampled once every six minutes, and the data are transmitted to the National Oceanic and Atmospheric Administration computers at INEL. In addition to this equipment, total sky and normal-incidence solar radiation instruments were installed this last year to provide data for agricultural experiments in Raft River and to supplement solar data collected at the Energy Experiment Station at Idaho State University.

Representative data from the weather station are shown in Figures 5, 6, and 7. The wind rose for 1977 is typical of those for past years. The predominant wind direction is 240 degrees, while less than $26 \%$ of all winds originate between 270 and 90 degrees. Winds over $48 \mathrm{~km} / \mathrm{hr}$ occur only $0.08 \%$ of the time, while calms, on the average, occur $6.3 \%$ of the time.

Average monthly temperatures varied only slightly from historic data. Precipitation, on the other hand, varied significantly from historic monthly values. May was an abnormally wet month, with a total precipitation of $89 \mathrm{~mm}, 30 \%$ of the total annual precipitation that year. The fall of 1977 was dry, with precipitation averaging only $33 \%$ the historic value. 


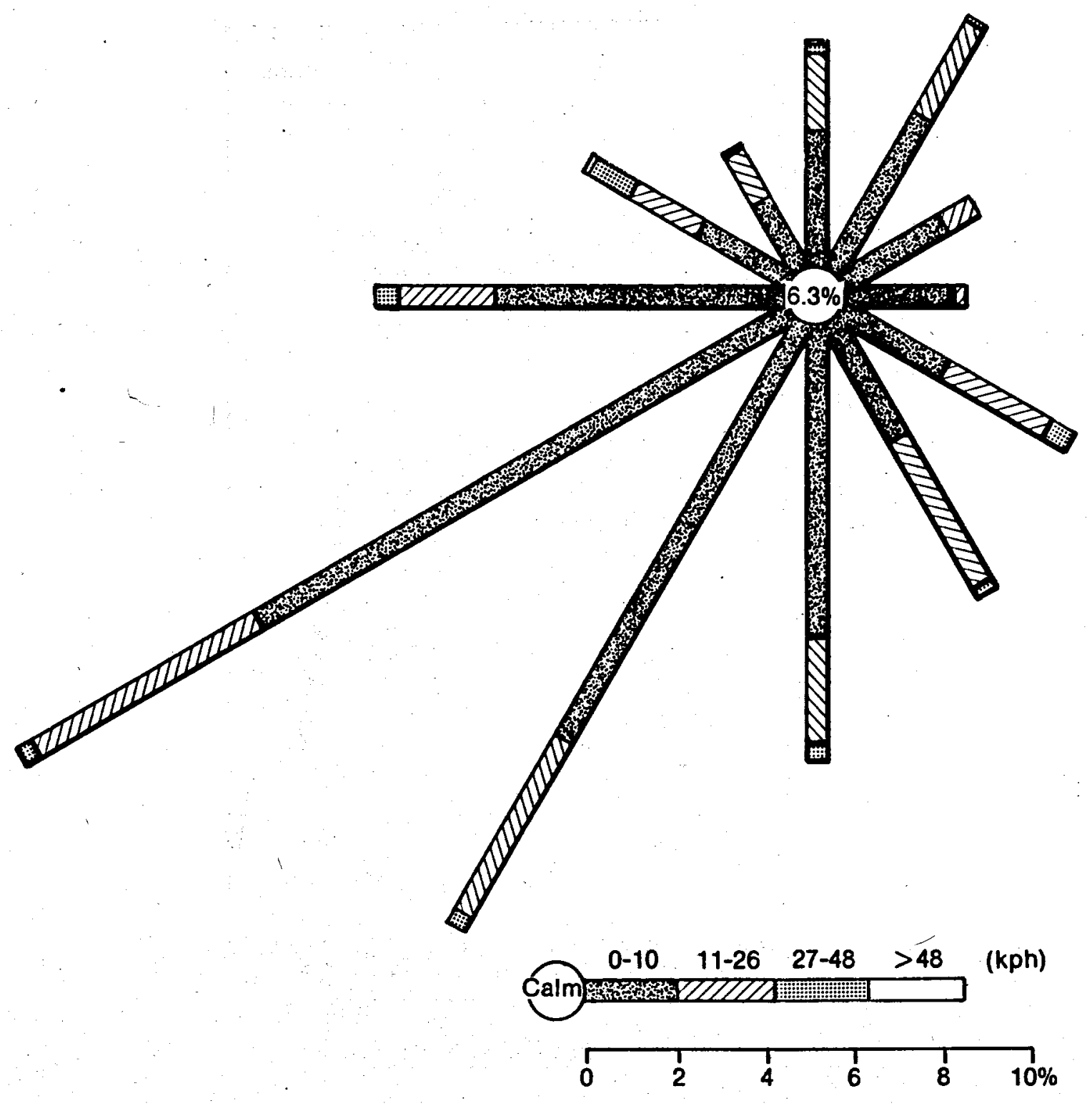

INEL-A-10 936

Fig. 5 Raft River 1977 wind rose. 


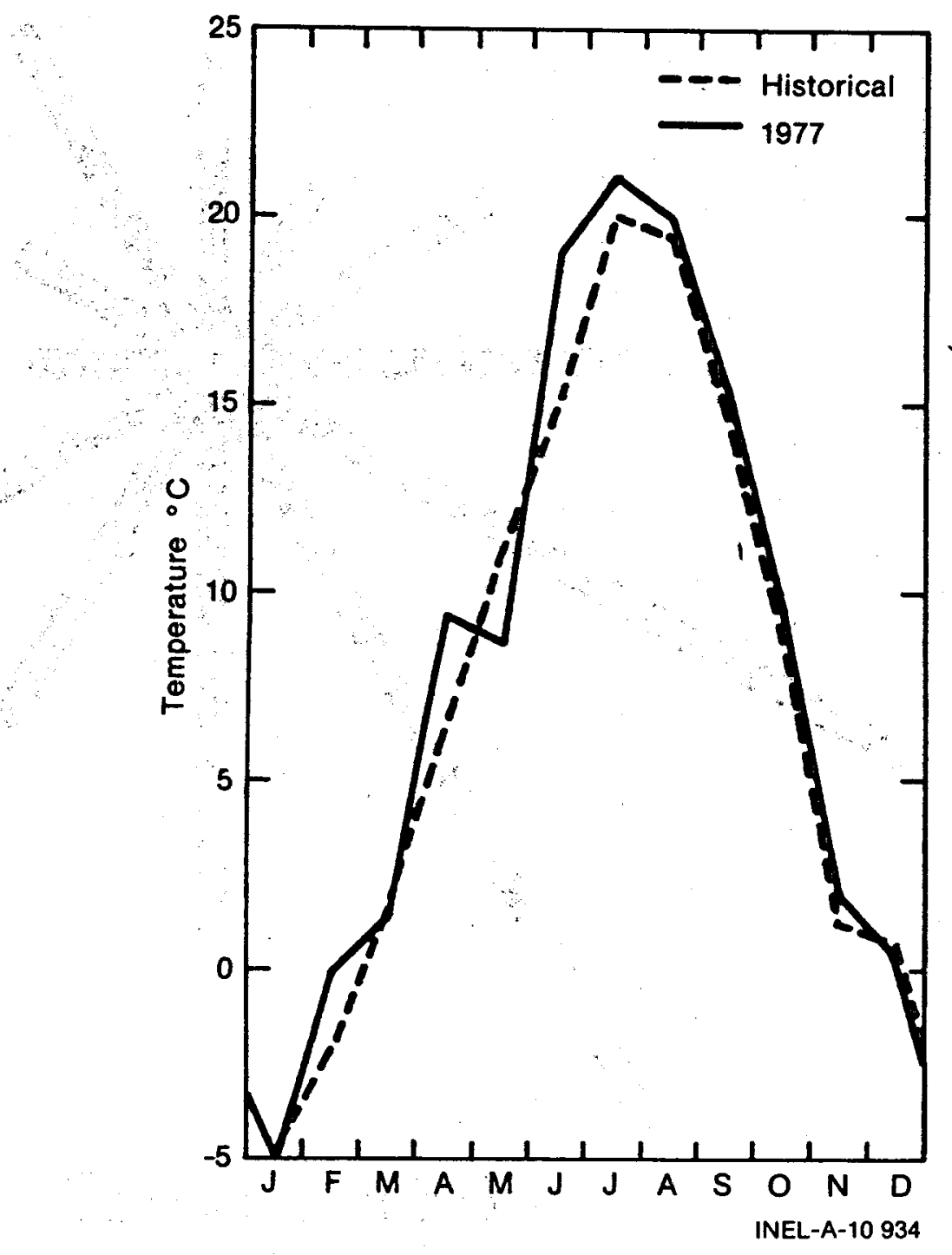

Fig. 6 Raft River 1977 temperature. 


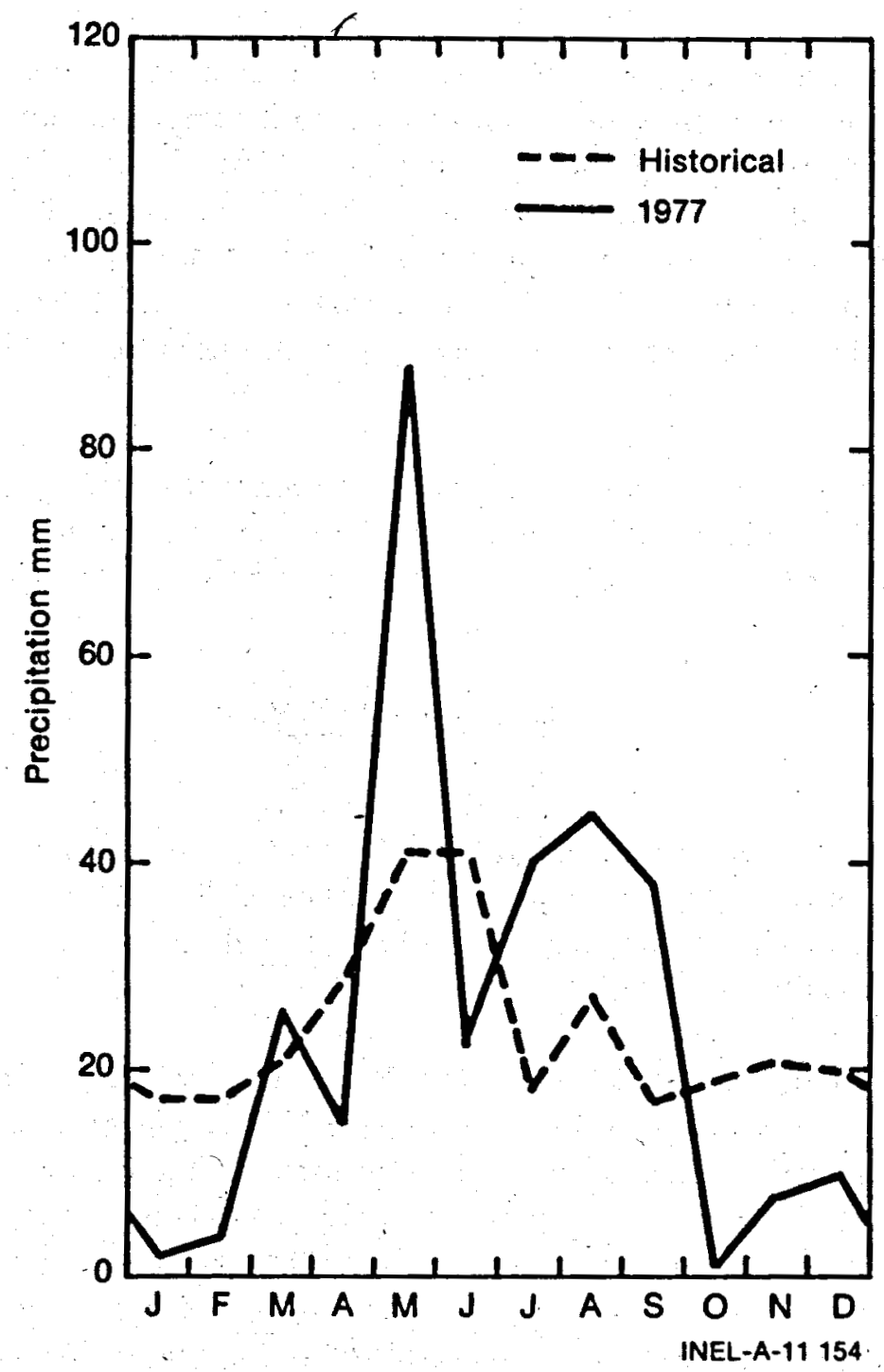

Fig. 7 Raft River 1977 precipitation.

\section{SUBSIDENCE}

A survey by B. E. Lofgen[2] of historical subsidence determined that as much as $0.9 \mathrm{~m}$ of subsidence had occurred in the lower Raft River valley as a result of irrigation pumping. In June 1975,169 points on a $400-\mathrm{m}$ grid were established and tied into the USGS grid for the purpose of checking elevations in the geothermal development area. In 1975 and 1976, two sets of levels were run on a 2.4-km square in the center of the original grid and closed in segments. In October 1977 and June 1978, 59 elevation points were surveyed over an area encompassing the five wells drilled or located at that time. With the exception of five points, the changes in elevation from the $1975^{\circ}$ survey were within the expected error of the level runs. Three of the five points are in cultivated fields and may have been disturbed. To date, there is no indication of any settlement; however, none of the geothermal wells has been tested at high fluid volumes over a long period of time. 
At the current time, the production wells are clustered on the northwest side of the Raft River, while the injection wells are located 1.5 to $2.5 \mathrm{~km}$ to the southeast. Long-term production and injection during the operation of various facilities, including the 5-MW power plant, may result in significant hydrologic changes because of this "polarization" of well locations with respect to known fault structures. Because the geothermal resource is not a closed system, pressure changes are not necessarily confined to the source aquifer(s). In some areas, these pressure changes may be transmitted to shallower aquifers of unconfined sediments.

As long-term production and injection tests are conducted on the geothermal wells in Raft River, several specific elevation surveys will be made, and the data will be correlated with changes in water level or artesian pressure in monitor wells (see pages 21 through 29).

\section{WATER QUALITY}

The water-quality monitoring program can be divided into four parts: (a) routine field monitoring of irrigation wells and the Raft River; (b) detailed sampling of geothermal wells; (c) independent semiannual sampling of shallow groundwater and surface water; and (d) injection-well monitoring.

Using field laboratory facilities in Raft River, weekly analyses are performed on samples from five water sources near the geothermal development area. The data would provide a warning signal if significant changes occurred in these water sources. Analyses include $\mathrm{pH}$, fluoride, chloride, hardness, alkalinity, and conductivity. The mean and standard deviations for these components for each water source are shown in Table IV. In general, the variability in the data collected so far is within expected values. The Raft River shows some of the widest fluctuations as a result of spring runoff, low summer flows, and irrigation return flows.

Detailed analyses of fluids produced from the geothermal wells are conducted during flow tests. The results are used to determine the potential environmental consequences of utilizing the fluids in various experiments and tests, to determine fluid "incompatibilities" and corrosion-scaling potential, and to provide input to theories on the source(s) and extent of the geothermal resource. The currently available analyses of the seven deep geothermal wells drilled in the Raft River valley are shown in Table V. There has been relatively little sampling of RRGI-7, because the well is not artesian at the wellhead. Therefore, the results shown may not be entirely indicative of the composition of the fluids at depth.

The Idaho Department of Water Resources conducts semiannual surveys of irrigation wells and the Raft River to provide independent information on the quality of water in these sources. To date, eight surveys have been completed. The quality of the Raft River exhibits significant seasonal variation but varies only slightly by location. The quality of irrigation wells, which generally produce from the 30 - to $150-\mathrm{m}$ depth, varies significantly 
TABLE IV

WATER QUALITY - RAFT RIVER WATER SOURCES

(Raft River Field Lab)

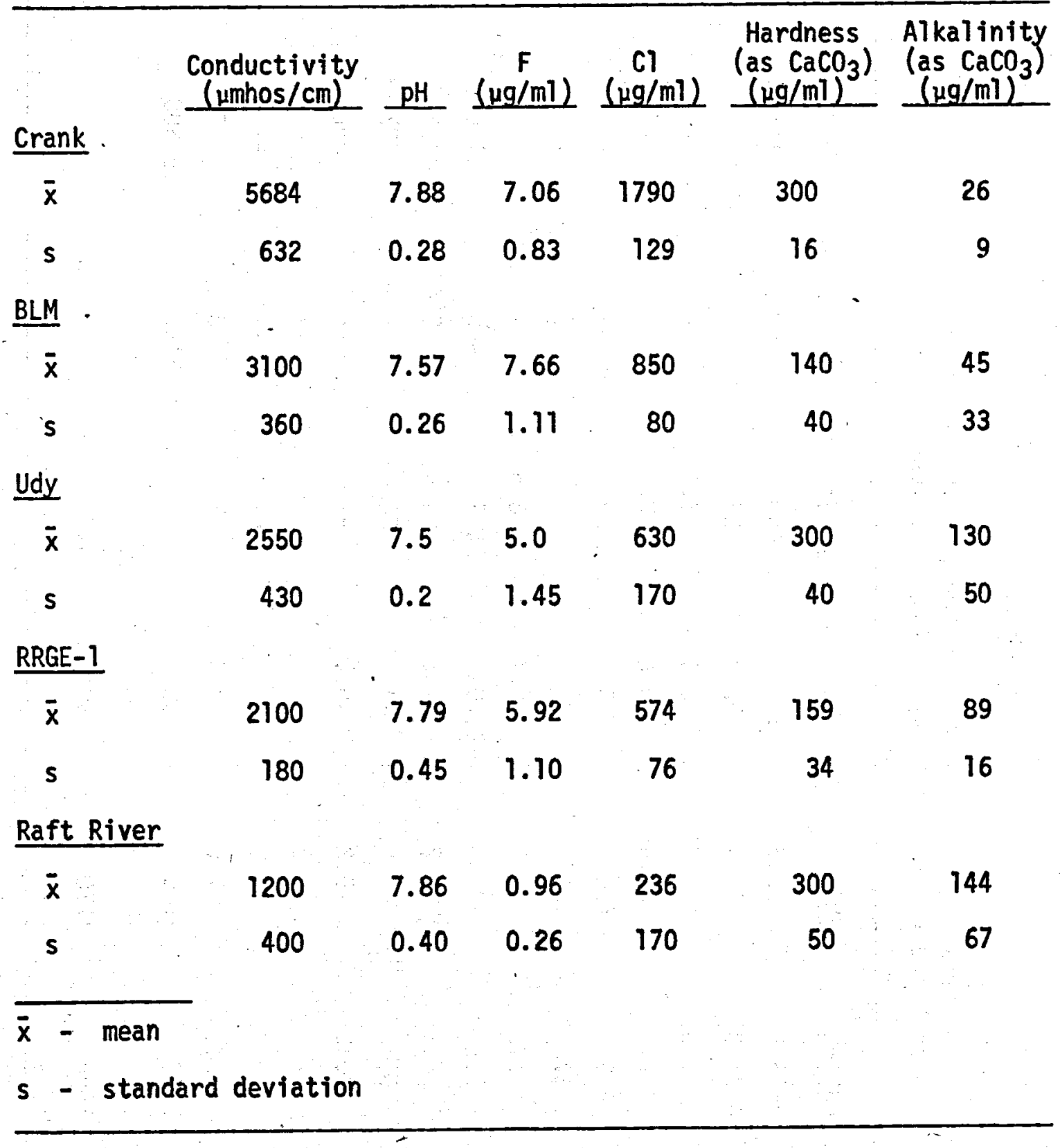

with location and depth. The quality of water in shallow $(<40 \mathrm{~m})$ wells approximates that of the Raft River in most locations. Deeper wells west of the geothermal development and to the north toward Malta produce relatively good-quality water (specific conductance averages $1400 \mu \mathrm{mhos}$ ). Within 3 to $5 \mathrm{~km}$ of the geothermal development, irrigation wells show the influence of the geothermal resource: temperatures increase by approximately $10^{\circ} \mathrm{C}$, silica content increases, and overall water quality decreases (specific conductance averages $3000 \mu \mathrm{mhos}$ ). 
TABLE V

CHEMICAL ANALYSIS OF RAFT RIVER GEOTHERMAL WATER

(Mean Value of Available Data - In mg/l Unless Otherwise Noted)

\begin{tabular}{|c|c|c|c|c|c|c|c|}
\hline & RRGE-1 & RRGE-2 & RRGE-3 & RRGP -4 & RRGP -5 & RRGI- & RRGI-7 \\
\hline $\mathrm{Ca}$ & 53.5 & 35.3 & 193 & 150 & 40 & 157 & 315 \\
\hline$K$ & 31.3 & 33.4 & 97.2 & 28 & - & -- & -- \\
\hline Li & 1.5 & 1.2 & 3.1 & 3.1 & -- & -- & $\Delta-$ \\
\hline $\mathrm{Mg}$ & 2.4 & 0.6 & 0.6 & 0.2 & - & - & 1.6 \\
\hline $\mathrm{Na}$ & 445 & 416 & 1185 & 1525 & - & $-=$ & 2,000 \\
\hline Si & 57 & 61 & 74 & 51 & 67 & - & 39 \\
\hline$s r$ & 1.6 & 1.0 & 6.7 & 6.5 & - & $\cdots$ & -- \\
\hline $\mathrm{Cl}^{-}$ & 776 & 708 & 2170 & 2575 & 900 & 3,150 & 4,085 \\
\hline $\mathrm{F}^{-}$ & 6.3 & 8.3 & 4.6 & 4.5 & 8.4 & 8.5 & 5.0 \\
\hline $\mathrm{HCO}_{3}^{-}$ & 64 & 41 & 44 & 24 & -- & 37 & 26 \\
\hline $\mathrm{NO}_{3}^{-}$ & $<0.2$ & $<0.2$ & $<0.2$ & -- & -- & $-\cdots$ & $*$ \\
\hline$s=$ & - & .0 .3 & -- & 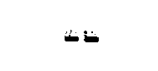 & - & $-\infty$ & $=-$ \\
\hline $\mathrm{SO}_{4}^{=}$ & 60 & 54 & 53 & 61 & $=-$ & -- & 64 \\
\hline$\quad \mathbf{p H}$ & 8.4 & 7.6 & 7.3 & 7.4 & 8.1 & $\quad 7.3$ & -- \\
\hline $\begin{array}{l}\text { Conductivity } \\
(\mu \mathrm{mhos} / \mathrm{cm})\end{array}$ & 3370 & 2740 & 9530 & 7280 & 2150 & 10,500 & 12,000 \\
\hline TDS & 1560 & 1270 & 4130 & 4470 & $=$ & - & $=$ \\
\hline
\end{tabular}


Selected results from the 1978 surveys are compared to previous surveys in Figure 8. The 1978 values are within the expected range of natural fluctuations for the wells shown, all of which are near the geothermal development. One irrigation well $7 \mathrm{~km}$ northwest of the development has shown significant changes in water quality during the past three years (Table VI). The conductivity of this well more than doubled between August 1975 and August 1977. Most of this was due to an increase in chloride, with calcium, magnesium, sodium, and sulfate also showing significant increases. Nearby wells did not show similar fluctuations during the same period, indicating that geothermal development was probably not the cause. Subsequent chemical analyses of water from that well and nearby domestic and irrigation wells have not yielded an explanation for the fluctuations.

Between June 18, 1978, and June 29, 1978, a total of 90 metric tons (MT) of salt (NaC1) were used to "kill" RRGP-5 during fishing operations for lost drill pipe. Additionally, $30 \mathrm{MT}$ of $\mathrm{NaCl}$ were dumped directly into the reserve pits. Of the total amount of $120 \mathrm{MT}$ salt used, an estimated $5 \mathrm{MT}$ were removed from the hydrologic system. Because the well was only cased to $460 \mathrm{~m}$, concern arose that shallow and intermediatedepth aquifers could be contaminated, either as a result of seepage from the reserve pit or by seepage into thief zones in the uncased section of the borehole. Depth-dependent changes in the conductivity of RRGP-5 provided a model of groundwater flow in and around the well. Estimates by Allen and McAtee ${ }^{[3]}$ indicated that at least $16 \mathrm{MT}$ of salt entered the aquifer at a depth of $490 \mathrm{~m}$.

Seventeen domestic and irrigation wells were sampled up to three times weekly, beginning five days after the salt was first used. These samples were analyzed in the field for conductivity, chloride, and sodium. Trends in these water quality parameters during the sampling period were compared to baseline conditions. To date, none of the data show any indication of salt contamination. 


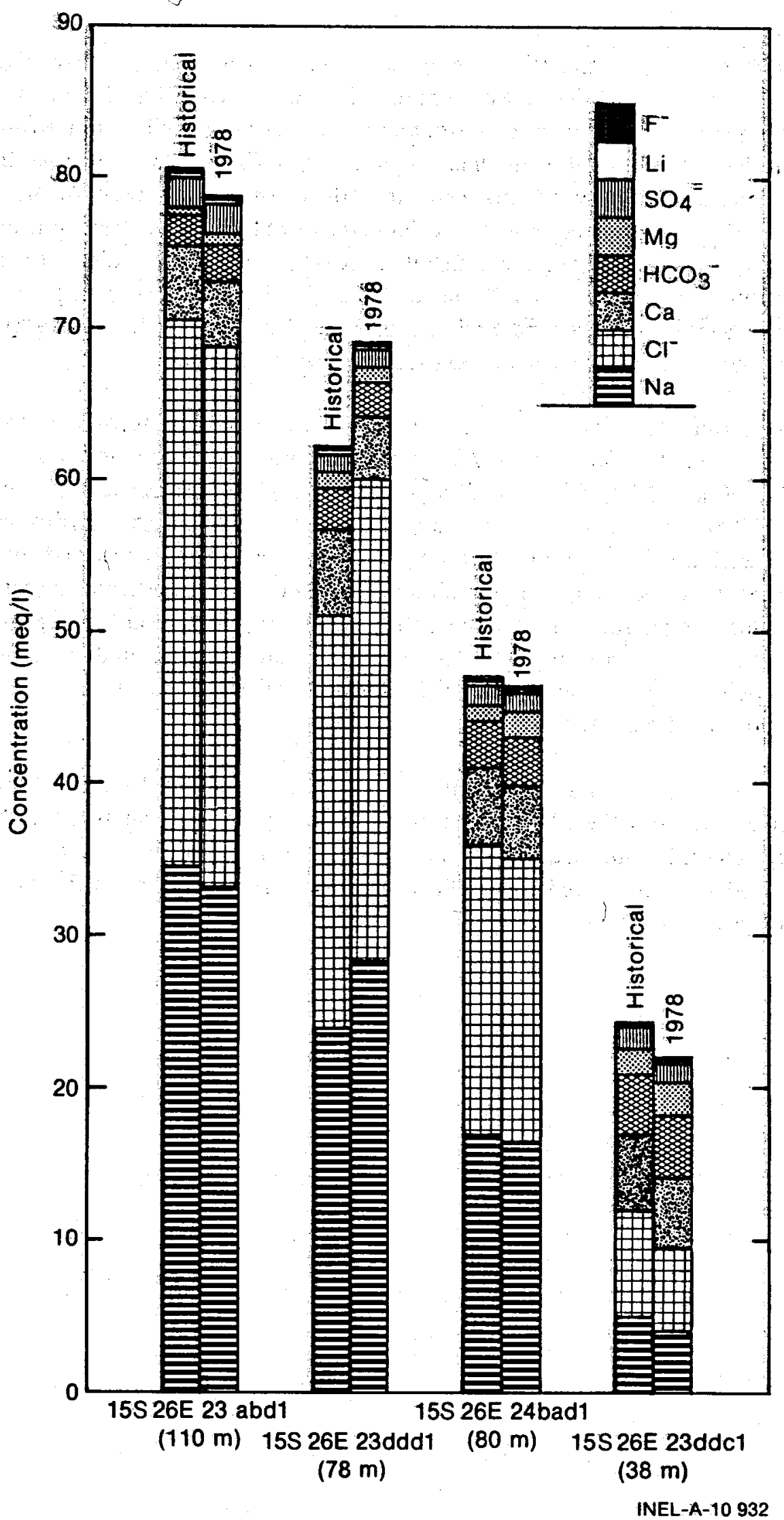

Fig. 8 Water chemistry surveys of selected irrigation wells. 


\section{TABLE VI}

WATER QUALITY - IRRIGATION WELL 14S $27 E$ 32bdḍ

(In $\mathrm{mg} / 1$ Unless Otherwise Noted)

\begin{tabular}{ccccc}
\hline & $8 / 75$ & $6 / 77$ & $9 / 77$ & $8 / 78$ \\
\cline { 2 - 3 } & 206 & 542 & 363 & 287 \\
$\mathrm{~K}$ & 10 & 13 & 10 & - \\
$\mathrm{Li}$ & 0.16 & 0.21 & 0.23 & 0.26 \\
$\mathrm{Mg}$ & 37 & 103 & 68 & - \\
$\mathrm{Na}$ & 193 & 378 & 254 & 575 \\
$\mathrm{SiO}_{2}$ & 49 & 51 & 38 & 44 \\
$\mathrm{Cl}^{-}$ & 525 & 1402 & 966 & 1266 \\
$\mathrm{~F}^{-}$ & 0.72 & 0.61 & 0.47 & 0.58 \\
$\mathrm{HCO}_{3}^{-}$ & 278 & 352 & 301 & 341 \\
$\mathrm{SO}_{4}^{-}$ & 111 & 408 & 194 & 322 \\
$\begin{array}{c}\text { Conductivity } \\
\text { (umhos/cm) }\end{array}$ & 2250 & 5300 & 3500 & 4750 \\
\hline
\end{tabular}

\section{MONITOR WELLS}

As geothermal studies progressed in Raft River, it became apparent that there is hydraulic communication between the geothermal system(s) and the shallower aquifers that have been developed for irrigation and domestic water supplies. Because of this natural communication, there is some concern that the development of the geothermal resources in the valley may adversely affect the chemical quality or supply of water in the shallower aquifers.

Declining water levels in the shallower aquifers indicated that recharge to these aquifers was not adequate to meet demand [4]. As a result, the state closed the basin to further water resource development. Currently, the geothermal system is included in that closure.

In November 1977 an aquifer monitoring program was initiated and seven monitor wells were drilled. The objectives of this monitoring program were: (a) to evaluate the 
natural communication between aquifers; (b) to provide information to be used by the state in deciding if the geothermal system should be excluded from the closure of the basin; and (c) to quantify the effects of production and injection of geothermal fluids on shallow aquifers.

The monitor wells were drilled to varying depths in the shallower aquifers and were located around the injection well field (Figure 9). Monitor well locations were based on the assumption that injection of geothermal fluids at intermediate depths of 600 to $1000 \mathrm{~m}$ would have a greater potential for adversely affecting shallower aquifers than would the deep production wells. The construction, temperature logs, and initial water quality for the monitor wells are shown in Figures 10 and 11 and in Table VII. MW-1 is the deepest of the wells, with a total depth of $399 \mathrm{~m}$. Three of the wells are $150 \mathrm{~m}$ deep, corresponding to the deepest irrigation well in the vicinity. The temperature profiles indicate that $M W-3$ and MW-4 have similar thermal characteristics, as do MW-5, MW-6, and MW-7 as a group. MW-2 has the highest thermal gradient indicating the greatest influence from the deeper geothermal system.

MW-1 and MW-2 were equipped with pressure transducers to monitor injection tests on RRGI-4 during the spring of 1978. In addition, water levels, wellhead pressures, and/or artesian flow rates were monitored on fourteen other wells: the USGS-3 corehole ( $434 \mathrm{~m}$ ), the BLM flowing well $(126 \mathrm{~m})$, the BLM offset well $(122 \mathrm{~m})$, the Crook greenhouse well $(165 \mathrm{~m})$, seven irrigation wells, the USGS 4 corehole $(77 \mathrm{~m})$, and two USGS auger holes (11 and $26 \mathrm{~m}$ ). The last three wells are upgradient, hydrologically, from the geothermal development and were used to monitor natural fluctuations of the water table.

During the period from March 21, 1978, to June 10,1978 , a total of $12,800 \mathrm{~m}^{3}$ of water was injected into RRGI-4 at rates ranging from $16 \mathrm{l} / \mathrm{s}$ to $51 \mathrm{l} / \mathrm{s}$. The longest test lasted for 13,300 minutes, during which time the injection rate was $441 / \mathrm{s}$. A pressure response was seen in MW-1 and USGS-3 during each of the injection tests (Figure 12). During the longest test, pressure increases of 34 and $97 \mathrm{kPa}$ were seen in MW-1 and USGS-3, respectively. The water level in the BLM offset well rose over $1 \mathrm{~m}$ during the same period. The responses at USGS-3 and the BLM offset well were much larger than expected, indicating that the intermediate-depth aquifer system is heterogenous and anisotropic. The response of USGS-3 to injection was also much larger than the well's response to seasonal hydrologic changes or to past geothermal development activity (Figure 13). Comparisons by W. L. Niemi and L. B. Nelson [5] of well logs and well locations with known fault systems indicate that USGS-3 and RRGI-4 penetrate the same fracture system, while MW-1 penetrates unfractured rock adjacent to the fracture system.

Water samples were taken from each of the monitor wells before and after the injection tests, and from the flowing BLM and Crook wells during the tests. No change in water quality was detected.

Injection tests in RRGI-6 and RRGI-7 will begin in early 1979. The monitor wells, nearby irrigation wells, and USGS wells will be monitored for changes in water quality, pressure, or water level. RRGI4, MW-1, MW-2, and USGS-3 will be used to monitor 


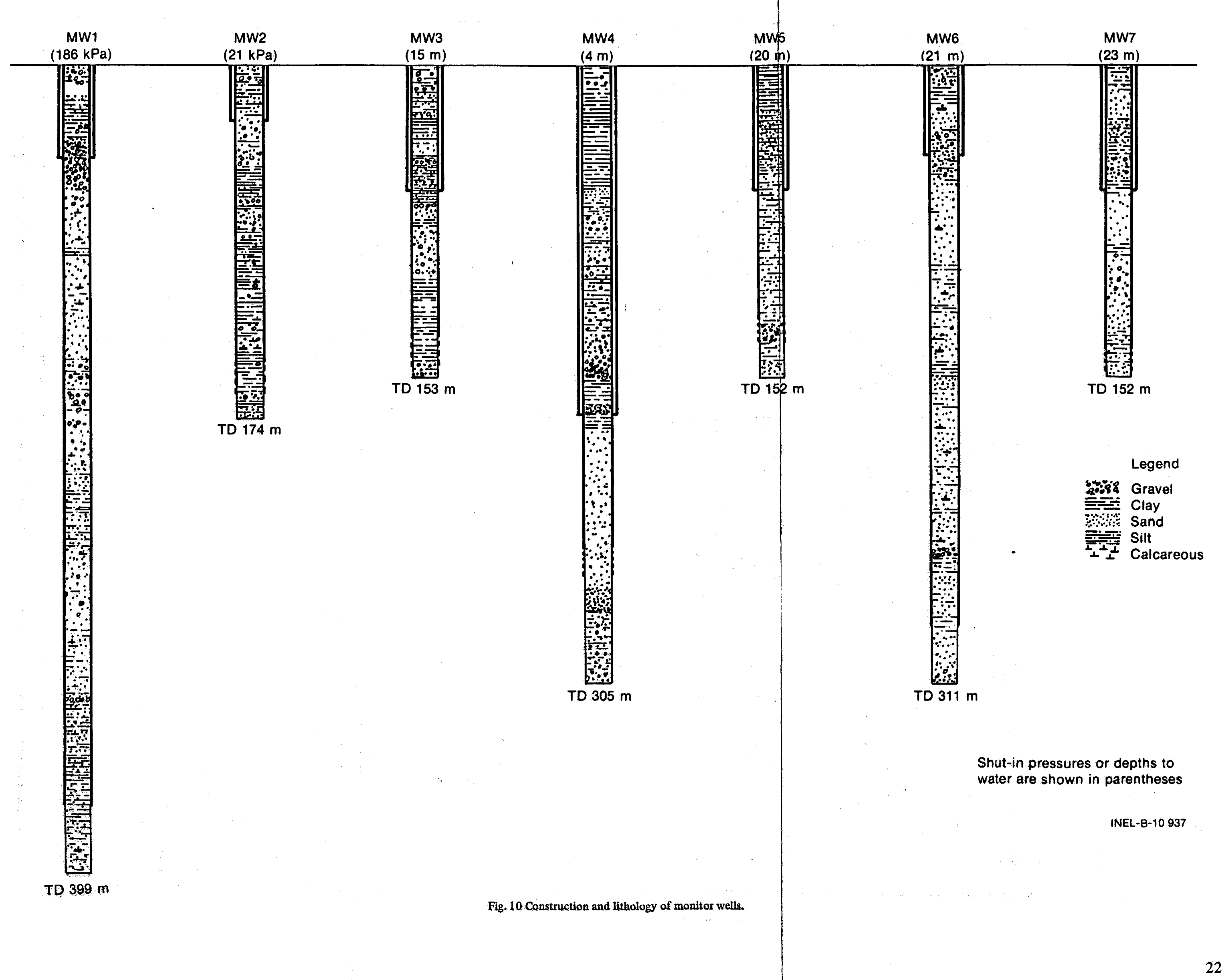




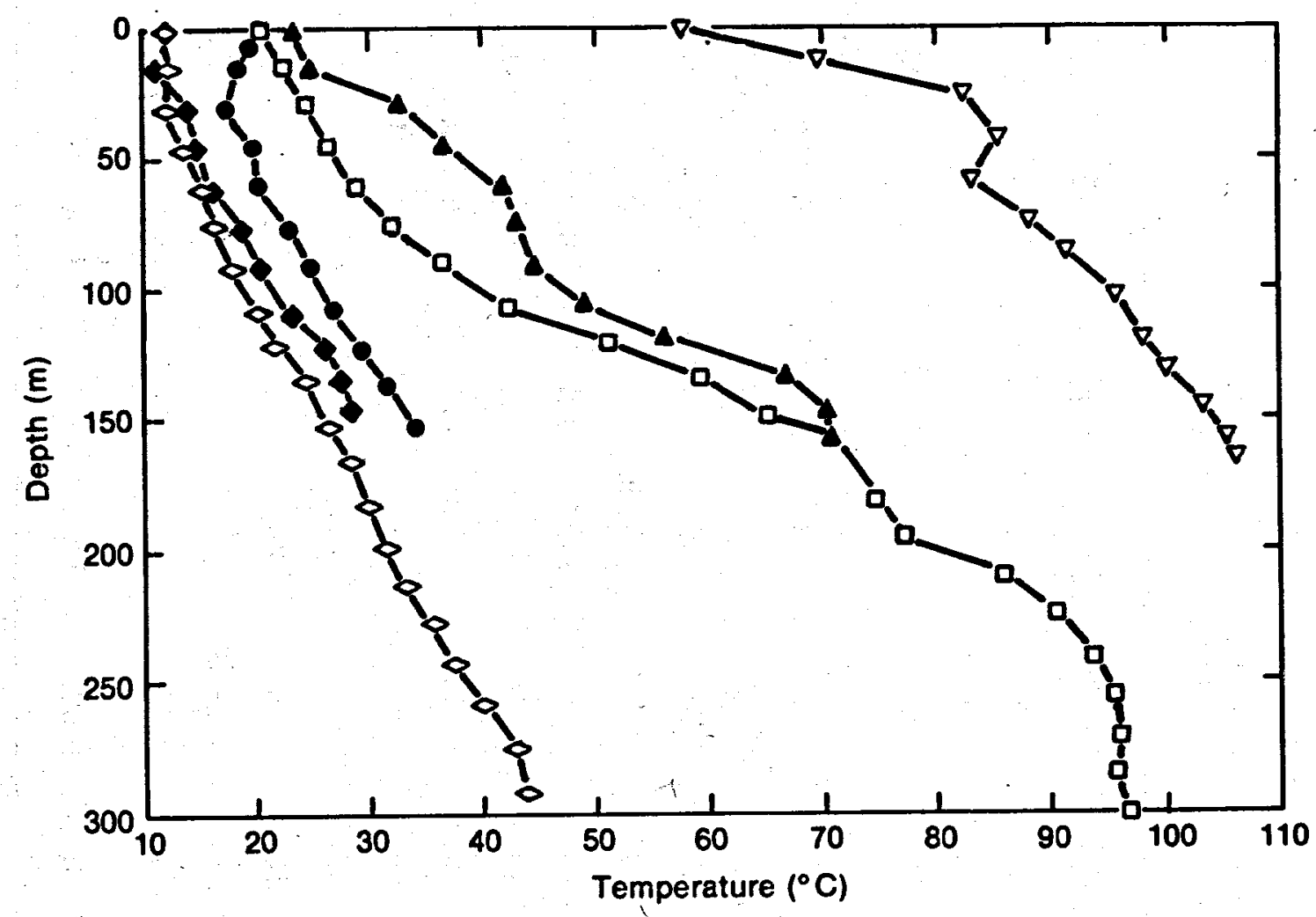

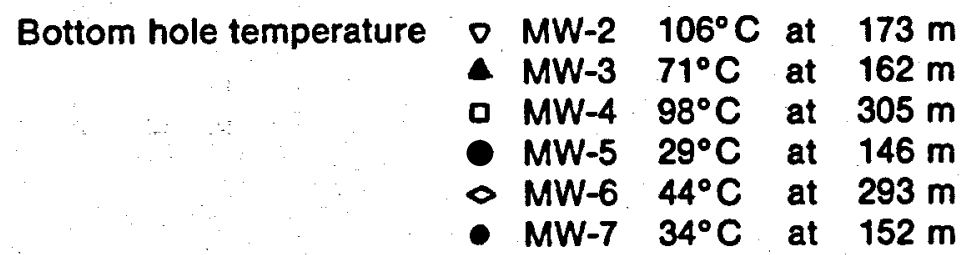

INEL-A-10 935

Fig. 11 Temperature profiles of monitor wells.

production tests later this year. All wells will be monitored during hydrofracturing and well stimulation tests planned for mid-1979. Upon completion of initial resource.testing in early 1980 , a report on the results and initial conclusions from monitoring injection and production tests will be issued. 
TABLE VII

INITIAL WATER QUALITY - MONITOR WELLS

(Mean Value of Available Data - In mg/l Unless Otherwise Noted).

\begin{tabular}{|c|c|c|c|c|c|c|c|c|c|c|}
\hline & $M W-1$ & $M W-2$ & $M W-3$ & $M W-4$ & $M W-5$ & $M W-6$ & $M W-7$ & USGS -3 & BLM & Crook's \\
\hline $\mathrm{Ca}$ & 193 & 118 & 173 & 189 & 164 & 193 & 102 & 60 & 42 & 108 \\
\hline $\mathrm{Fe}$ & 0.3 & 0.5 & 7.6 & 12.8 & 5.7 & 0.3 & 7.6 & -- & 0.1 & 0.1 \\
\hline$K$ & 31 & 25 & 54 & 25 & 20 & 58 & 13 & 16 & 21 & 30 \\
\hline Li & 3.8 & 2.6 & 2.9 & 3.4 & 2.5 & 2.6 & 1.1 & 2.1 & 1.5 & 2.5 \\
\hline $\mathrm{mg}$ & 0.36 & 0.6 & 4.0 & -- & -- & -- & 23 & 0.3 & 0.2 & 0.4 \\
\hline $\mathrm{Na}$ & 2,060 & 1400 & 1290 & 1390 & 210 & 1230 & 340 & 2090 & 570 & 1170 \\
\hline $\mathrm{SiO}_{2}$ & 78 & 86 & 97 & 74 & 59 & 36 & 39 & 62 & 82 & 91 \\
\hline $\mathrm{NH}_{4}^{+-}$ & 1.4 & 0.08 & 0.62 & 1.7 & 0.05 & -- & 0.06 & -- & 0.4 & 0.3 \\
\hline $\mathrm{Cl}^{-}$ & 3,590 & 1640 & 2410 & 2440 & 610 & 2380 & 650 & 1870 & 890 & 1770 \\
\hline $\mathrm{CO}_{3}=$ & $<1$ & $<0.1$ & -- & $<1$ & -- & $<1$ & -- & 0 & $<1$ & $<1$ \\
\hline $\mathrm{F}^{-}$ & 2.7 & 5.6 & 5.1 & 6.2 & 0.5 & 3.7 & 1.0 & 4.9 & 6.7 & 5.6 \\
\hline $\mathrm{HCO}_{3}^{-}$ & 25 & 28 & 50 & 40 & -- & -- & 104 & 50 & 35 & 33 \\
\hline $\mathrm{NO}_{3}^{-}$ & 0.6 & 0.02 & 0.09 & 0.09 & 0.4 & -- & 2.9 & - & 0.5 & 0.9 \\
\hline $\mathrm{SO}_{4}=$ & 68 & 60 & 50 & 43 & 44 & 63 & 28 & 62 & 55 & 49 \\
\hline $\mathrm{pH}^{4}$ & 8.1 & 7.5 & 7.6 & 7.9 & 7.8 & 9.8 & 7.8 & 8.1 & 7.7 & 8.1 \\
\hline $\begin{array}{l}\text { Conductivity } \\
(\mu \mathrm{mhos} / \mathrm{cm})\end{array}$ & 11,200 & 5740 & 6100 & 7700 & 2000 & 7020 & 2250 & 6600 & 3200 & 6000 \\
\hline TDS & 6,300 & 3200 & 4350 & 4000 & 1240 & 4660 & 1380 & 3360 & 1700 & 3300 \\
\hline
\end{tabular}




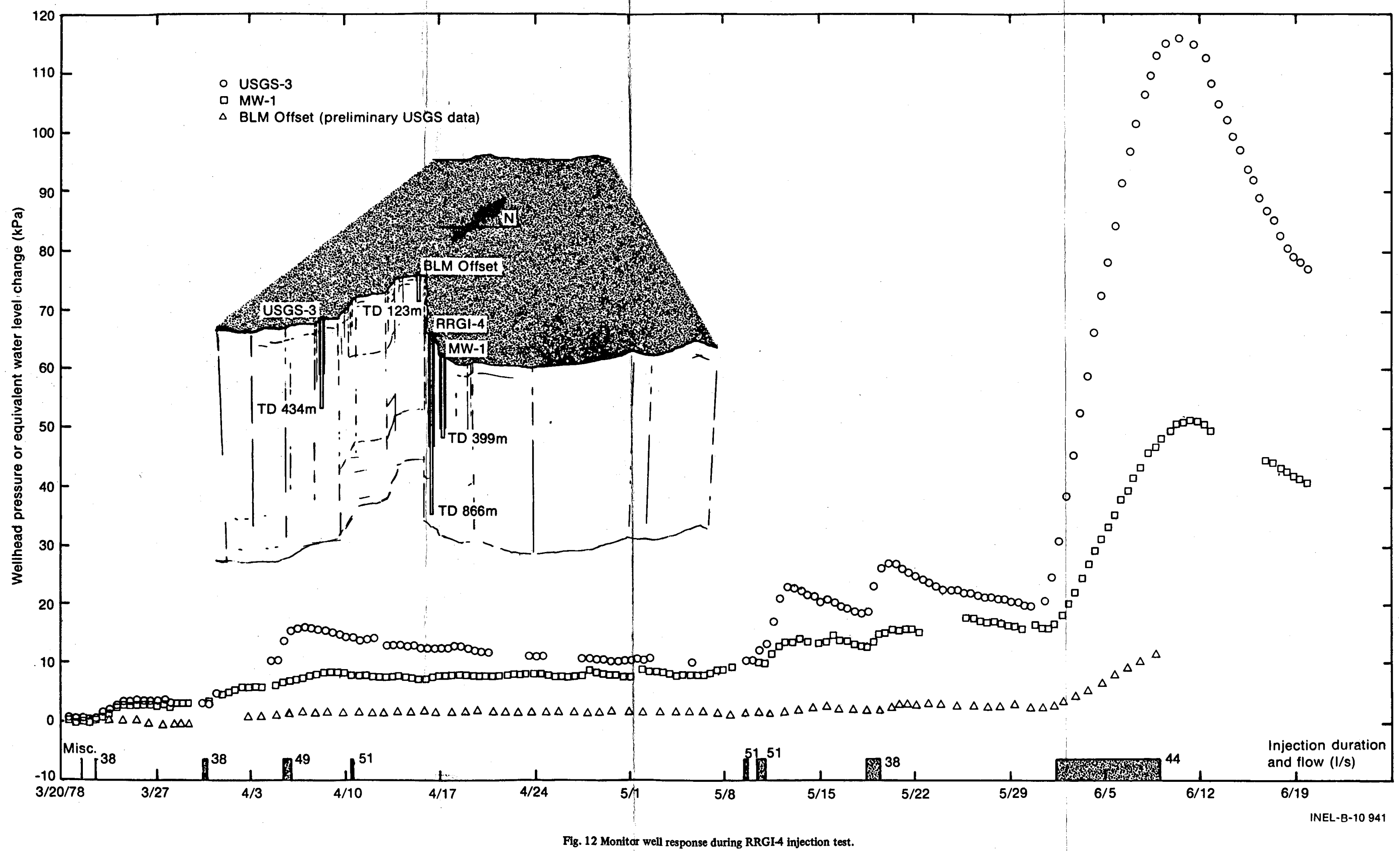



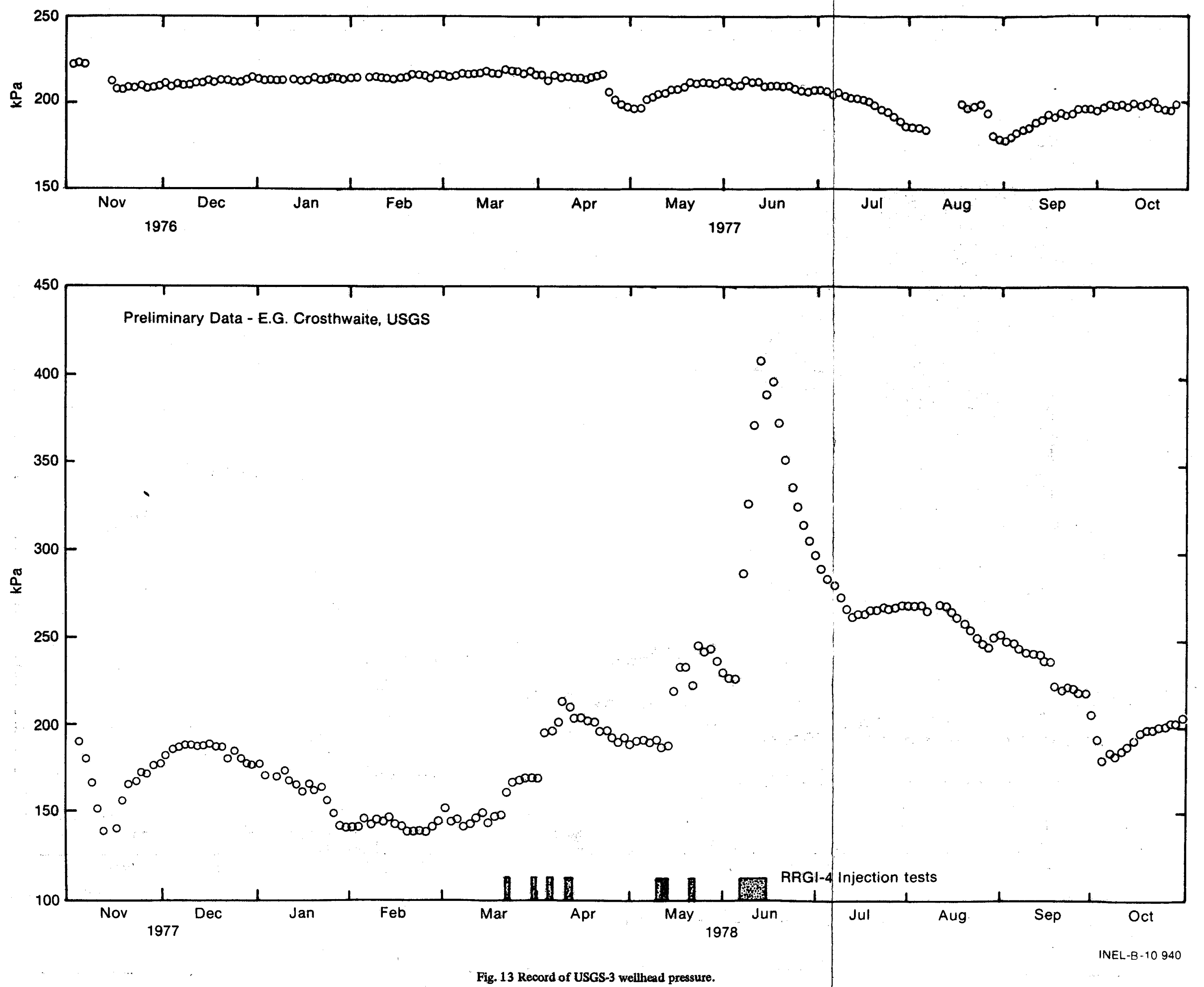


\section{BIOLOGICAL ENVIRONMENT MONITORING PROGRAMS}

\section{SOILS AND FLORA}

The Raft River valley is classified as a cold desert steppe. The climatic factors and marginal soil conditions combine to make natural revegetation a very slow process. In May 1976 soil and vegetation research was initiated in the vicinity of the Raft River geothermal development. The objectives of this research are to characterize the existing baseline conditions, to identify fragile communitites, and to determine ideal species for revegetation of disturbed areas.

During the first growing season, vegetation community patterns were mapped for a $26 \mathrm{~km}^{2}$ area surrounding the geothermal development site (Figure 14). Nineteen permanent study plots were established in representative plant communities for initial characterization and subsequent variation analyses. The plot soils were sampled and analyzed for selected edaphic characteristics, and climatic variables were measured at selected sites. Plot vegetation was examined for species 'frequency and cover. Moisture-stress measurements were made for selected species, to obtain a comparative evaluation of the moisture conditions of the soil in each permanent plot, as well as to provide information on the vegetation response to the moisture as measured by the amount of stress the plants were under.

In 1977, four new plots were added and two new climatic stations were established. The new plots were placed in plant community types not adequately represented in the 19 original plots. They coincided with faunal study plots and the streamside and shadscale communities. Initial vegetation surveys were conducted on the new plots, and composite soil samples were analyzed for the same characteristics as the 1976 samples. These plots will be included in all future studies.

Vegetation studies were repeated in the 1977 and 1978 growing seasons (with the exception of vegetation mapping and soil analysis in plots already sampled). The plots were read in 1977 and in 1978, using the same methods and measuring at approximately the same time of year, to show baseline variation from year to year.

Soil factors were investigated (the same characteristics that were analyzed in 1976) for the four new plots and for soil pits dug in the various community types in the area. These factors included soil texture (sand, silt, clay, and rock fraction); cation exchange (CEC); electrical conductivity $\left(\mathrm{EC}_{\mathrm{e}}\right.$, or total salinity); $\mathrm{N}, \mathrm{Na}, \mathrm{K}, \mathrm{Ca}, \mathrm{Mg}$, and $\mathrm{Cl}$ concentrations; soil acidity ( $\mathrm{pH}$ ); sodium absorption ratio (SAR); exchangeable sodium percentage (ESP); and carbon (organic) and carbonate $\left(\mathrm{HCO}_{3}\right)$ concentrations.

The climatic stations were monitored periodically during the growing seasons, using rain canisters for measuring precipitation, maximum/minimum thermometers for recording ambient temperatures, and temperature indicators placed in the soils at root zone depth for 


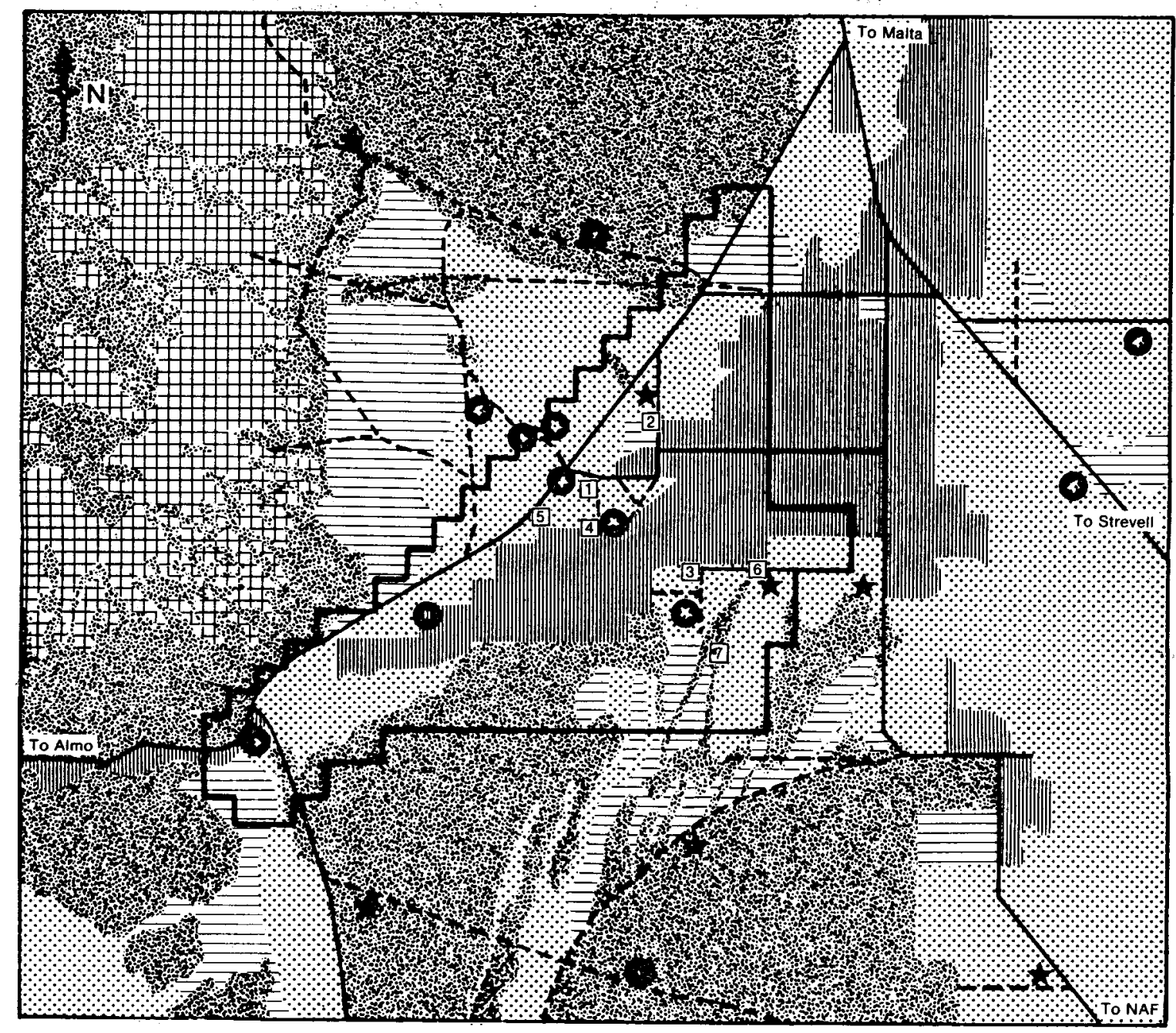

Fields

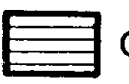

Grass - Winterfat

Greasewood

䎴 Pinyon - Juniper

Shebrush

- Plots with Climate Station

$\star$ Plots

INEL-A-10 931

(1) Geothermal Wells

Fig. 14 Map of vegetation and permanent plots. 
monitoring soil temperatures. The data obtained from monitoring the climate stations will be helpful in assessing the climatic effect on the vegetative response in the various plant communities. Another series of moisture stress measurements was taken with a Cleary pressure chamber to assess moisture conditions for selected plant species growing at each plot. These factors will be correlated with vegetative characteristics to determine the statistical trends these factors might influence.

Soil characteristics seldom change appreciably unless there is some extremely disrupting phenomenon, usually caused by man's activities. The soil data are applicable from year to year as a rather stable environmental factor; thus, soils were not sampled repetitively during 1977 and 1978.

The data collected during 1977 and 1978 have been summarized in certain categories; these include species frequency, average living-vegetation cover, perennial grass cover, perennial forb cover, annual cover, and cryptogam cover (mosses and lichens). The following tasks are in progress:

\section{(1) Tabulation of data}

(2) Multiple regression correlations between vegetation characteristics and the climatic and edaphic variables (with significance tests)

(3) Comparisons between 1976, 1977, and 1978 data (trends will be analyzed for any significant effects on or from geothermal developments)

(4) Written discussion of methods, results, and conclusions for the 1977 and 1978 reports

(5) More extensive analyses of 1978 data, such as cluster and/or possible principal components analysis (a discriminant analysis)

(6) Publications of draft and final copies of 1977 and 1978 reports.

Copies of the 1977 report can be obtained through EG\&G's Geothermal Program, Biological and Earth Sciences Branch. The 1978 report will be available from the same source on May $1,1979$.

\section{FAUNA}

Faunal populations, including species of small mammals, insects, and common birds, were studied throughout the 1977 and 1978 seasons (May through September) in the vicinity of the Raft River geothermal site. The objectives of the study were: (a) to establish 
a data base for use in future impact assessment; (b) to develop methods for continually monitoring population changes in key biota; and (c) to select key species and sampling locations for establishing a permanent monitoring program. Dr. Clive Jorgensen, Dr. Clayton White, Dr. Clyde Pritchett, Sanford Porter, and Dan Landeen, through the Zoology Department at Brigham Young University, have been instrumental in the design and execution of this research effort. Their results to date are available in a comprehensive technical report [6]. The following is a brief summary.

\subsection{Small Mammals}

Small mammal populations merit consideration because they are the primary herbivores in the semiarid desert that characterizes the Raft River valley. Small mammals also serve as the prey base for carnivorous mammals and raptors; thus, they represent a key trophic level in energy flow and nutruent cycling through the desert ecosystem.

A base sampling control grid with a $12 \times 12$ pattern was established in a sagebrush-greasewood community. Two live traps were placed at each of the 144 stations and were checked twice daily for 10-day periods in May and August. Additionally, satellite minigrids were established in 13 communities representative of the main vegetation types/biotic communities found in the geothermal area. The minigrids were sampled for five days periodically throughout the summer. Data from the minigrids were compared to the control-grid data to determine if human or construction activities altered small mammal densities and/or distribution. Additionally, male reproductive activity was studied by sacrificing the organisms and examining the testes.

No significant differences in male reproductive activity were evident. The preferences among small mammal species for certain habitat types was evident from the study, and will be useful for future monitoring.

\subsection{Common Birds}

The overall impact of geothermal development on bird communities, rather than populations, is being assessed in and near the geothermal area. Baseline data on density and composition of breeding birds, density and success of nests, and composition of stable winter populations have been collected during the past two years. Five sample sites were chosen to correspond with locations for which vegetation data were already available. Dominant species were the Brewer's sparrow, sage sparrow, horned lark, and sage thrasher. The species diversity of the general area was found to be quite low. It appeared the sage sparrows are the most selective in their habitat requirements and, thus, could potentially be impacted by geothermal development should extensive habitat destruction occur. It is felt that the best indicators of development-related impacts on bird populations will be either changes in density of breeding birds or alterations in numbers or distribution of sage sparrows. 


\subsection{Insects}

The insect community is composed of hundreds of species. Identification and classification of these species is not economically feasible at Raft River, since such a task would require extensive investigative effort and several years. To assess the potential impacts of geothermal development on natural insect communities, a smaller system was chosen for study. Since ants and aphids may be: (a) tied closely through symbiotic relationships; or (b) competitive with birds and mammals for food resources, the population structure and interactions of these species was studied. Once known, deviations from the baseline can be assessed as part of the biological monitoring effort.

Results are still inconclusive; however, preliminary conclusions are available. Harvester ant populations were studied via use of a fluorescent ink marking technique. It was found that foraging harvester ants can be used to assess relative numbers. A positive correlation between mound volume and densities of above-ground workers was determined; thus, the mound size could be used to estimate total ant densities in a given environment. Classification of the aphids is not yet complete; however, data will be used to determine relationships of the plant-aphid-ant interactions.

\section{RAPTOR DISTURBANCE RESEARCH}

With the intensifying demands of multiple land use and the rapidly expanding efforts to diversify the uses of certain renewable and nonrenewable resources, conflicts with wildlife and aesthetic values are increasing. In Raft River, the most evident conflict is between permanent developments and raptor populations. A raptor disturbance study was initiated in the Raft River valley during the 1978 nesting season to assess what impact, if any, geothermal development would have on the productivity and population dynamics of particular birds of prey.

The ferruginous hawk (Figure 15) is the largest member of the North American hawk family and is recognized as a species sensitive to disturbance. This hawk is prone to nest desertion, especially during incubation when the site tenacity of the female is weakest. Because of their sensitivity and apparent declining numbers over parts of their range, this specie has been placed in a category of concern by allocating it to a "blue list". This list indicates species that are, or seem to be, substantially reduced in numbers as a result of several factors, including habitat reduction and human impact. However, during years when high population densities occur in its food base, the hawk can be common and have a high reproductive output. Taken together, these facts may make the ferruginous hawk a good barometer of the effects of human disturbance during geothermal development.

The Raft River valley boasts a dense population of nesting ferruginous hawks, which typically occupy lone trees on the periphery of juniper stands. Approximately 58 nests were located in 1978, 27 of which were active. Nests were distributed rather uniformly to the east and west of the geothermal withdrawal (Figure 16), with a mean distance between nests of $4.4 \mathrm{~km}$ (range 0.8 to $8.0 \mathrm{~km}$ ). 


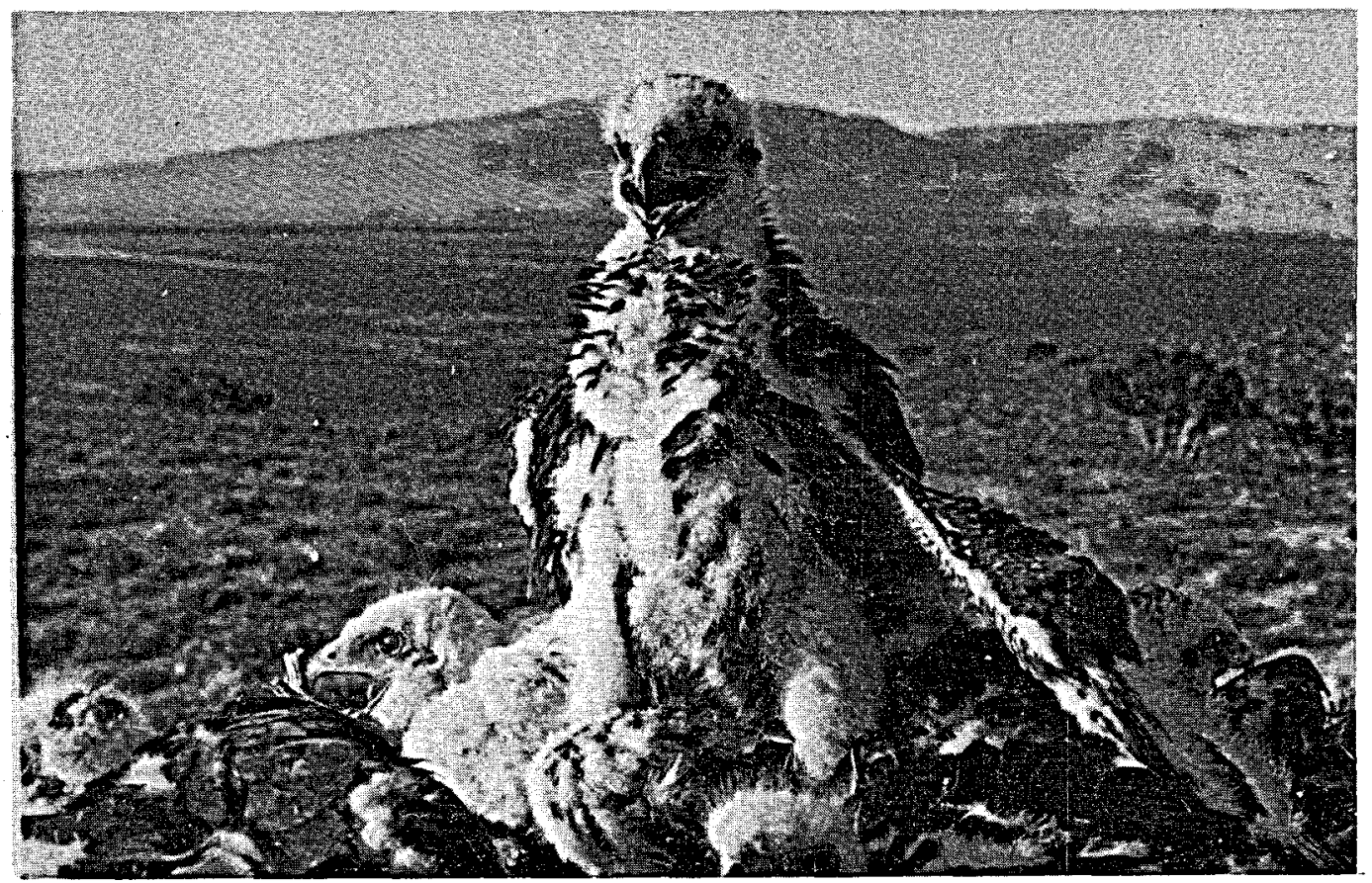

Fig. 15 Juvenile ferruginous hawk (Buteo regalis).

The objective of the research conducted during the 1978 nesting season (when sensitivity to disturbance is presumably at its highest) was to subject nests to a series of disturbances and to monitor the birds' responses to these disturbances. Both treatment and control nests were selected in early April. Four types of perturbations were applied to selected treatment nests beginning in May and lasting through the nesting period. Treatments were designed to simulate noises and/or disturbances encountered during routine operations at a development site. They included: (a) approaching nests on foot; (b) approaching nests in a closed vehicle; (c) discharging of firearms (an intermittent, abrupt noise) upon approaching the nests; and (d) continuously operating motors placed at given distances from nests.

Nests were disturbed repeatedly until the adults flushed (or left) the nest. Treatments and results are listed in Table VIII. Fledging rates from treatment and control nests are listed in Table IX. As the data indicate, no significant impacts resulted from perturbing the nests by discharging firearms in the vicinity or by placing continuously operating motors near the nests. However, only one young was fledged from the nests approached by vehicle, and walk-to nests fledged no young. Three nests were deserted by the adults: two approached on foot and one approached be vehicle.

The prey base was excellent in 1978, and it may in fact have raised the threshold of sensitivity of the organisms. The sensitivity threshold of some bird species is known to be lowered when adults are in poor physiological condition due to food stress, as evidenced by 


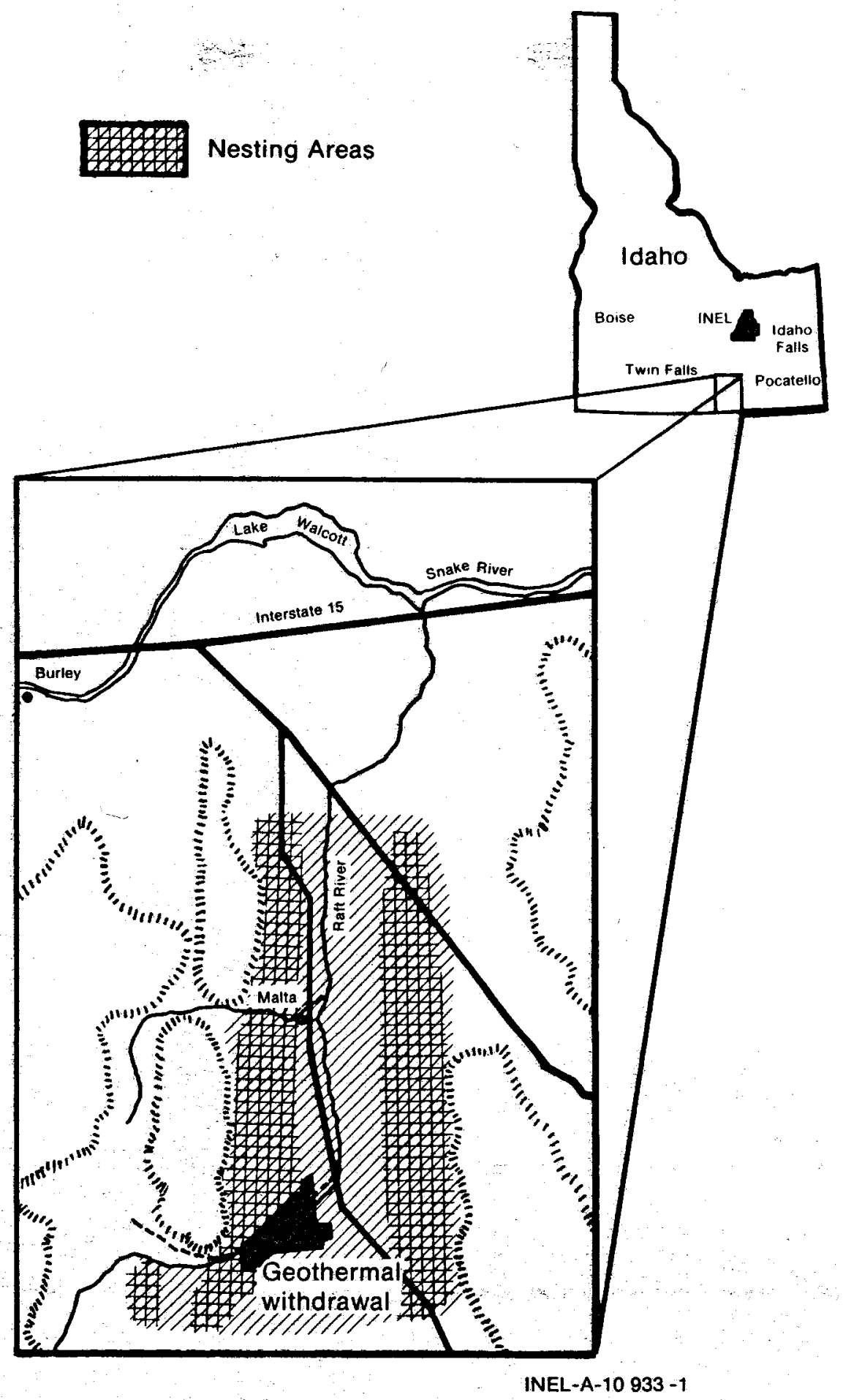

Fig. 16 Location of ferruginous hawk nests. 
TABLE VIII

TYPE OF IMPACT AND RESULTS AT TREATMENT NESTS

\begin{tabular}{|c|c|c|c|c|c|c|}
\hline Treatment & $\begin{array}{l}\text { Date } \\
\text { Treatment } \\
\text { Started } \\
\end{array}$ & $\begin{array}{l}\text { Date } \\
\text { Treatment } \\
\text { Ended } \\
\end{array}$ & $\begin{array}{l}\text { Number } \\
\text { of } \\
\text { Visits } \\
\end{array}$ & $\begin{array}{l}\text { Mean Flushing } \\
\text { Distance and } \\
\text { Range }(\mathrm{m}) \\
\end{array}$ & Results & Comments \\
\hline walk & May 3 & June 2 & 18 & $\begin{array}{c}31 \\
(14-137)\end{array}$ & depredated & $\begin{array}{l}\text { hatched ca. May } 11 \text {, } \\
\text { destroyed by predation } \\
\text { ca. May } 29\end{array}$ \\
\hline walk & May 4 & May 17 & 8 & $\begin{array}{c}110 \\
(23-183)\end{array}$ & deserted & -- \\
\hline walk & May 4 & May 4 & 6 & $\begin{array}{c}53 \\
(37-91)\end{array}$ & deserted & -- \\
\hline motor & May 13 & June 12 & 8 & $\begin{array}{c}65 \\
(37-201)\end{array}$ & $\begin{array}{l}\text { fledged } 4 \\
\text { young }\end{array}$ & -- \\
\hline motor & May 5 & May 29 & 8 & $\begin{array}{c}101 \\
(37-320)\end{array}$ & $\begin{array}{l}\text { fledged } 4 \\
\text { young }\end{array}$ & $\begin{array}{l}\text { eggs may have hatched } \\
\text { by May } 10\end{array}$ \\
\hline gun shots & May 11 & June 21 & 18 & $\begin{array}{c}71 \\
(23-230)\end{array}$ & $\begin{array}{l}\text { fledged } 2 \\
\text { Young }\end{array}$ & $\begin{array}{l}\text { eggs hatched ca. } \\
\text { May } 18\end{array}$ \\
\hline gun shots & May 10 & June 22 & 22 & $\begin{array}{c}96 \\
(5-274)\end{array}$ & $\begin{array}{l}\text { fledged } 2 \\
\text { young }\end{array}$ & $\begin{array}{l}\text { eggs may have hatched } \\
\text { by May } 12-13\end{array}$ \\
\hline gun shots & May 10 & June 22 & 19 & $\begin{array}{c}74 \\
(5-320)\end{array}$ & $\begin{array}{l}\text { fledged } 4 \\
\text { young }\end{array}$ & $\begin{array}{l}\text { eggs may have hatched } \\
\text { by May } 15\end{array}$ \\
\hline drive & May 10 & May 18 & 7 & $\begin{array}{c}217 \\
(18-484)\end{array}$ & deserted & -- \\
\hline drive & May 10 & May 17 & 6 & $\begin{array}{c}221 \\
(137-366)\end{array}$ & destroyed & nest destroyed by wind \\
\hline drive & May 10 & June 22 & 25 & $\begin{array}{c}62 \\
(18-484)\end{array}$ & $\begin{array}{l}\text { fledged } 1 \\
\text { young }\end{array}$ & $\begin{array}{l}\text { eggs hatched ca. } \\
\text { May } 19\end{array}$ \\
\hline
\end{tabular}


TABLE IX

FLEDGING RATES FOR 1978 . SEASON

\begin{tabular}{|c|c|c|c|}
\hline & No. Nests & $\begin{array}{l}\text { No. Young } \\
\text { Fiedged }\end{array}$ & $\begin{array}{c}\text { Fledging } \\
\text { Rate } \\
\end{array}$ \\
\hline A11 Treatment Nests & 9 & 17 & 1.88 \\
\hline Successful Treatment Nests & 6 & 17 & 2.83 \\
\hline \multicolumn{4}{|l|}{ Control Nests } \\
\hline Raft River Valley & 16 & 55 & 3.44 \\
\hline $\begin{array}{l}\text { Curlew and Black } \\
\text { Pine Valleys }\end{array}$ & 5 & 15 & 3.00 \\
\hline
\end{tabular}

fewer nesting pairs and poor clutch sizes. Thus, the 1978 season was a good production year and a year when population reductions due to the experimental impact were minimal. Consequently, the preliminary "buffer zone" recommendations may be liberal.

It appeared that treatment adults became sensitized to the researchers' presence and were not as attentive to their young as were controls; for example, one treatment pair did not brood their young during a severe rainstorm. Additionally, during banding, treatment adults were consistently absent from the nests while control adults were close to nests, appeared more concerned, and made defense gestures at the investigators.

As with most "biological indicator" studies, the data do not produce a standard formula for predicting development-related impacts. Based on current knowledge, a preliminary recommendation from the study is: human activity should be excluded within $0.8 \mathrm{~km}$ of known nesting locations, and construction activity should be excluded within $1.6 \mathrm{~km}$ of nests. Better estimates will be available following the 1979 nesting season. Utilizing the type of information generated in this study as siting criteria for future geothermal developments may enable development to take place compatibly with species normally sensitive to such activity. 


\section{HUMAN AND CULTURAL MONITORING PROGRAMS}

High fluoride concentrations are common in geothermal fluids; concentrations in Idaho range as high as $30 \mathrm{mg} / \mathrm{l}$. In Raft River, concentrations of fluoride range from 5 to $10 \mathrm{mg} / \mathrm{l}$ in the geothermal fluids, and high concentrations are found in some irrigation and domestic wells throughout the valley. Geothermal development has focused attention on the incidence of fluorosis in animals and people in the area. Previous studies have documented cases of fluorosis in cattle raised near the geothermal site, as a result of their exposure to water (nongeothermal) with high fluoride content and possibly as a result of alfalfa irrigated with this water[7].

In a companion study conducted by the Utah State Research Foundation (Dr. J. L. Shupe, Dr. Clyde Hurst, Dr. H. B. Peterson, and Research Associate A. E. Olson), the incidence of dental fluorosis was investigated in people living in the valley. The objectives of this study were to: (a) document "baseline" incidences of fluorosis; (b) provide a correlation between fluoride levels and fluorosis, which could be used in determining how and where geothermal fluids could be disposed of; and (c) alert people in the valley to domestic water supplies which may be the cause of some of the fluorosis.

During the spring of 1978, 270 school-aged individuals representing 151 families living in the vicinity of the geothermal area were examined. Of these, $132 \mathrm{had}$ some dental anomaly and 52 had lesions classified as typical dental fluorosis. Eleven of these had recently moved into the area. Teeth were classified according to a numerical code of 0 to 5 , with 0 being normal and 5 indicating severe fluoride-induced damage. The percentage of the group surveyed falling in each classification is shown in Table X. Color and black-and-white photographic records were made of selected cases (Figure 17). In addition to the dental surveys, analyses were made of culinary water supplies for families with individuals that had

\section{TABLE $X$}

\section{INCIDENCE OF FLUOROSIS}

\begin{tabular}{|c|c|c|}
\hline Dental Classification & \% of Group & 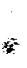 \\
\hline 0 - normal & 51 & \\
\hline 1 - questionable effect & 29 & \\
\hline 2 - slight fluoride effect & 16 & \\
\hline 3 - moderate fluoride effect & 3 & \\
\hline 4 - marked fluoride effect & 1 & \\
\hline
\end{tabular}




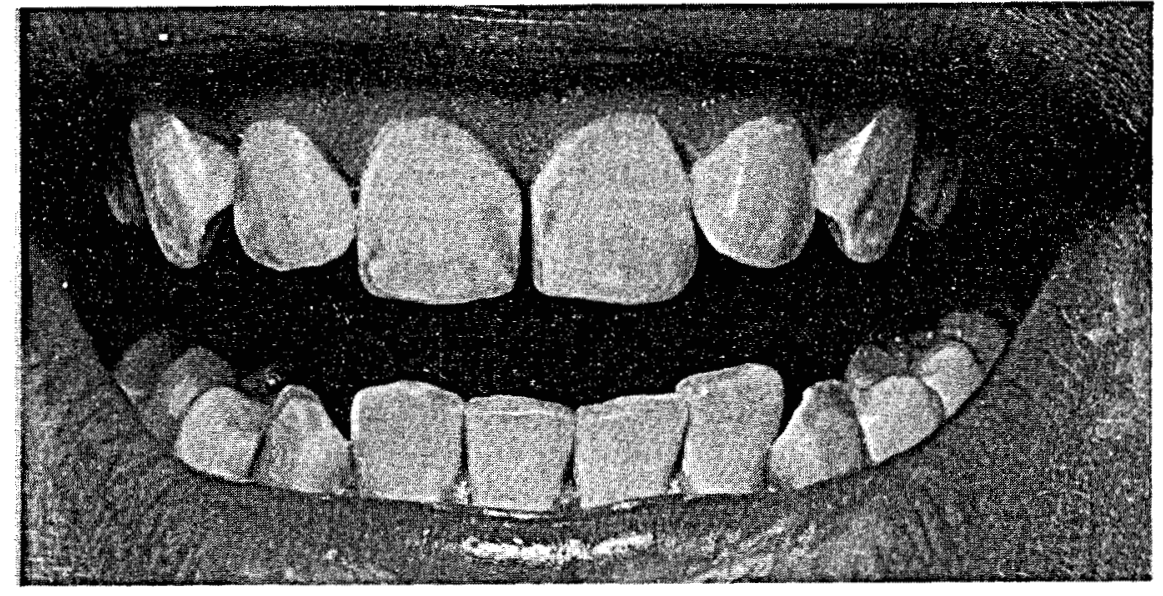

(a) 16.5-year-old female, moderate dental fluorosis; note horizontal, opaque, chalky-white striations; dental classification 3 ; as seen with front lighting.

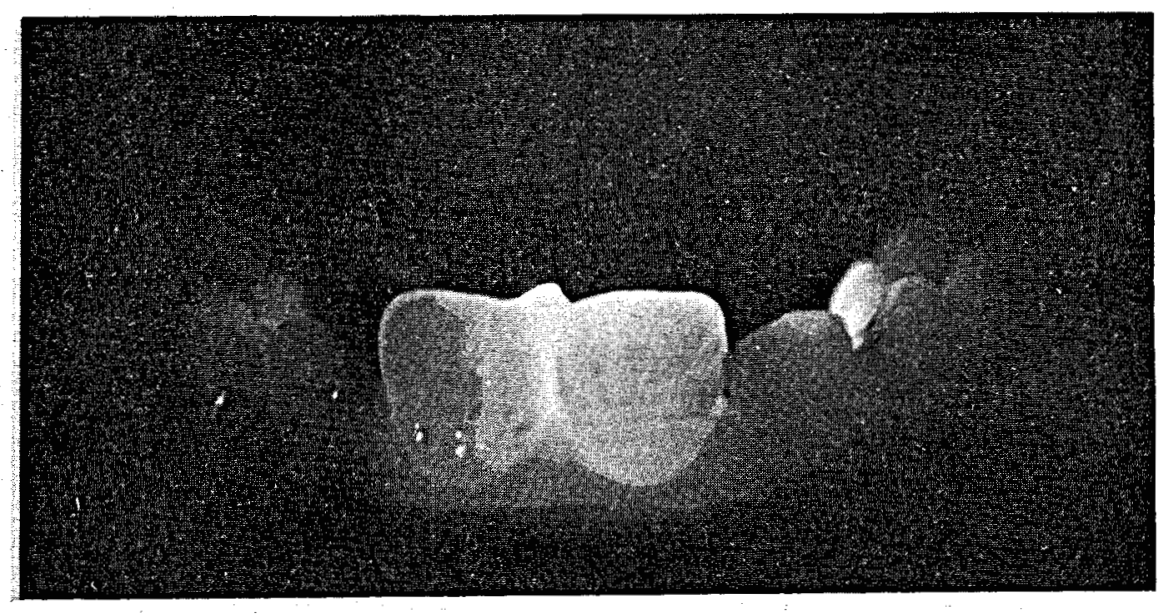

(b) Same teeth shown in above picture but viewed with small light placed behind the teeth to show different densities of horizontal hypoplastic striated areas.

Fig. 17 Teeth of selected fluorosis study subjects. 
definite dental lesions. The fluoride content in the 46 wells sampled averaged $0.8 \mathrm{mg} / 1$, with a range of 0.12 to $5.55 \mathrm{mg} / \mathrm{l}$. Six wells used for domestic consumption had fluoride levels greater than $1 \mathrm{mg} / \mathrm{l}$. Of the 10 individuals surveyed who used these wells, one was in dental classification 0 , three in classification 1 , four in classification 2 , and two in classification 3 .

Evaluation of the survey results indicated a rather high incidence of persons in dental classification 1. This incidence could be a result of metabolic disturbances such as high fevers, trauma, and some antibiotics. To date, the analytical results of fluoride contents in culinary waters do not indicate that there is enough fluoride in most of the waters sampled to induce the dental changes seen. In fact, most of the water samples do not contain fluoride in levels as high as those recommended by the American Dental Association and the American Medical Association.

Theories that might explain some of the lack of correlation between the water samples and the incidence of fluorosis include ingestion of fluoride from other sources, including food, vitamins, and toothpaste; individual variability (ranges of as much as 0 to $\mathbf{3}$ in dental classifications were seen within several families); analytical problems; and hydrological changes in the Raft River basin. Some people reported that the taste of their culinary water had changed, indicating a change in chemical composition. It is possible that the 1978 analyses do not represent historic levels of fluoride in the basin.

As a result of this study, culinary wells will continue to be sampled and analyzed for fluoride. Further evaluation of the sources of fluoride and their relation to incidences of dental fluorosis will be made. 


\section{SNAKE RIVER BASIN PROGRAM}

The Snake River Basin overview program, initiated in 1978, is designed to: (a) assess existing environmental baseline data for the eight known geothermal resource areas (KGRAs) in the Snake River drainage basin (Figure 18); (b) evaluate such data for inadequacies and gaps; and (c) develop a prioritized plan for supplementing existing data to achieve a solid environmental data base prior to any significant geothermal development on or near those areas with a high degree of geothermal potential.

A steering committee was established to serve as program consultants. It included representatives from the U.S. Bureau of Land Management, the U.S. Fish and Wildlife Service, the U.S. Geological Survey, the Lawrence Livermore Laboratory, the Idaho Department of Water Resources, the Idaho Conservation League, the National Oceanic and Atmospheric Administration, and the U.S. Department of Energy. The following steering committee meetings were held:

(1) May 19 in Idaho Falls - reviewed proposals and determined a strategy for issuing subcontracts

(2) June 20 in Boise - planned the initial workshop (i.e., format, participants, etc.)

(3) October 19 in Boise - reviewed status of project, made decisions on final report content and format, discussed scheduling and format, and planned the final workshop.

A workshop was held in Boise on July 20 with participants from local, state, and federal agencies; universities; and the private sector. Industry, although invited to attend, was not well represented. The objective of the workshop was to identify and discuss issues of concern in each of the Idaho KGRAs. Discussion groups were established for the following topics: (a) water quality and hydrology; (b) air quality and meteorology; (c) geology, subsidence, and seismicity; (d) socioeconomics and demography; and (e) flora and fauna. The groups identified concerns for their respective topics and suggested methods to mitigate such problems.

The primary considerations identified by each working group are summarized as follows:

Water Quality and Hydrology

(1) Resource definition: is "geothermal" a water or a mineral resource? 


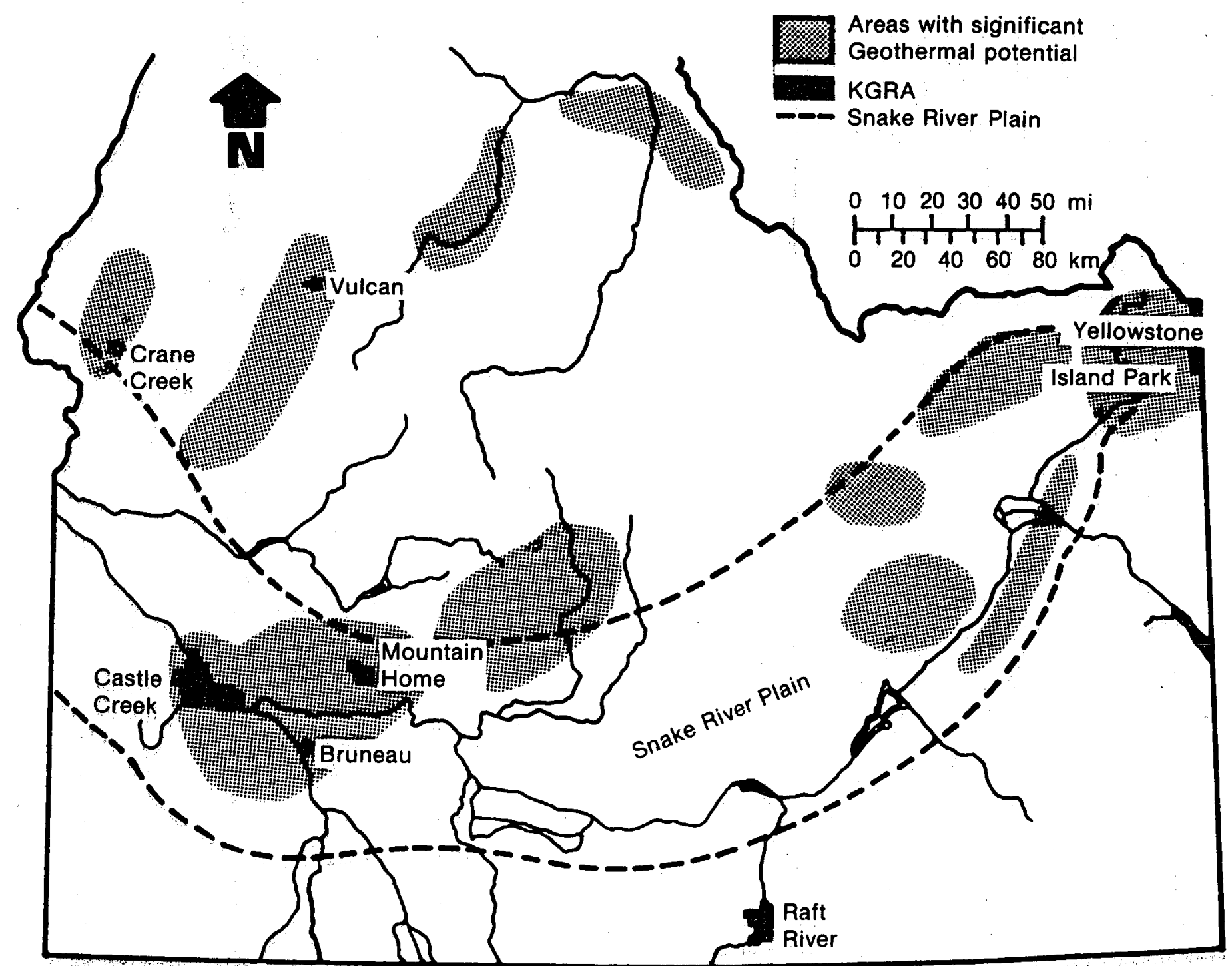

Fig. 18 Locations of known geothermal resource areas in Snake River Basin.

INEL-A-10 993 
(2) Lack of knowledge of the geothermal resource, including data on hydrologic boundaries, aquifer recharge, water quality of the geothermal resource, pressure changes, resource life span, and interrelationships of hot fluids, surface waters, and shallow groundwater systems

(3) Disposal of spent fluids: surface discharge versus injection

(4) Need for a monitoring network to include chemical parameters, temperature, water levels, and pressure of the geothermal aquifer

(5) Institutional factors: water laws (rights and usage) and water quality standards

Geology, Subsidence, and Seismicity

(1) Lack of data about Idaho KGRAs

(2) The need for quality data, including geologic mapping, geophysical mapping, subsidence and seismic monitoring, and test-well information

Flora, Fauna, and Soils

(1) Need for a complete environmental study prior to geothermal development (including predictable impacts on the biotic environment)

(2) Potential sensitive areas identified include: (a) raptor nesting sites; (b) antelope kidding grounds; (c) big-game migration routes; (d) natural streams, springs, and lakes; and (e) soils with high erosion hazard

(3) Factors related to surface water impacts: (a) depletion/reduction of flows; (b) thermal/chemical enrichment; (c) increased siltation from erosion; and (d) effects on sensitive or endangered species dependent on local waters

Air Quality and Aesthetics

(1) Air-quality impacts received little attention, since closed systems should mitigate problems associated with emission of $\mathrm{H}_{2} \mathrm{~S}$ and other noxious gases

(2) The positive impact of replacing fossil fuels with geothermal energy for space heating was identified 
(3) Long-term noise effects were assessed as being insignificant, with cooling-tower noise similar to the low hum of a waterfall

(4) Aesthetic impacts were assessed as "beauty is in the eyes, ears, nose, and pocketbook of the beholder"

\section{Socioeconomics and Demography.}

(1) Population increases in previously rural, nonindustrial areas will increase demands for urban services, increase tax revenues, and require land-use planning and control systems

(2) Geothermal development will result in cost-of-living increases (housing and taxes), will likely impact existing industries, and could result in the need for development of adequate community leaders, depending on the extent of the development.

Each group was presented with a "simulated environment" (Figure 19) and asked to indicate areas which they would consider for geothermal development given existing conditions (e.g., land ownership and use, protected habitat, migration routes, heritage resources, water resources, known geothermal phenomena). The objective of this exercise was to require the participants to set their priorities relative to resource use, considering all components of the environment. The results yielded information relative to the concerns of the public, developers, and regulatory agencies, while identifying concerns and potential conflicts. Land-use priorities, as established by responses of all participants to a questionnaire, were as follows:

(1) watershed protection

(2) consideration for fish and wildlife

(3) agriculture

(4) geothermal development for direct-use applications

(5) geothermal development for electrical production

(6) range

(7) timber

(8) visual aesthetics

(9) roadless/wilderness areas

(10) minerals 


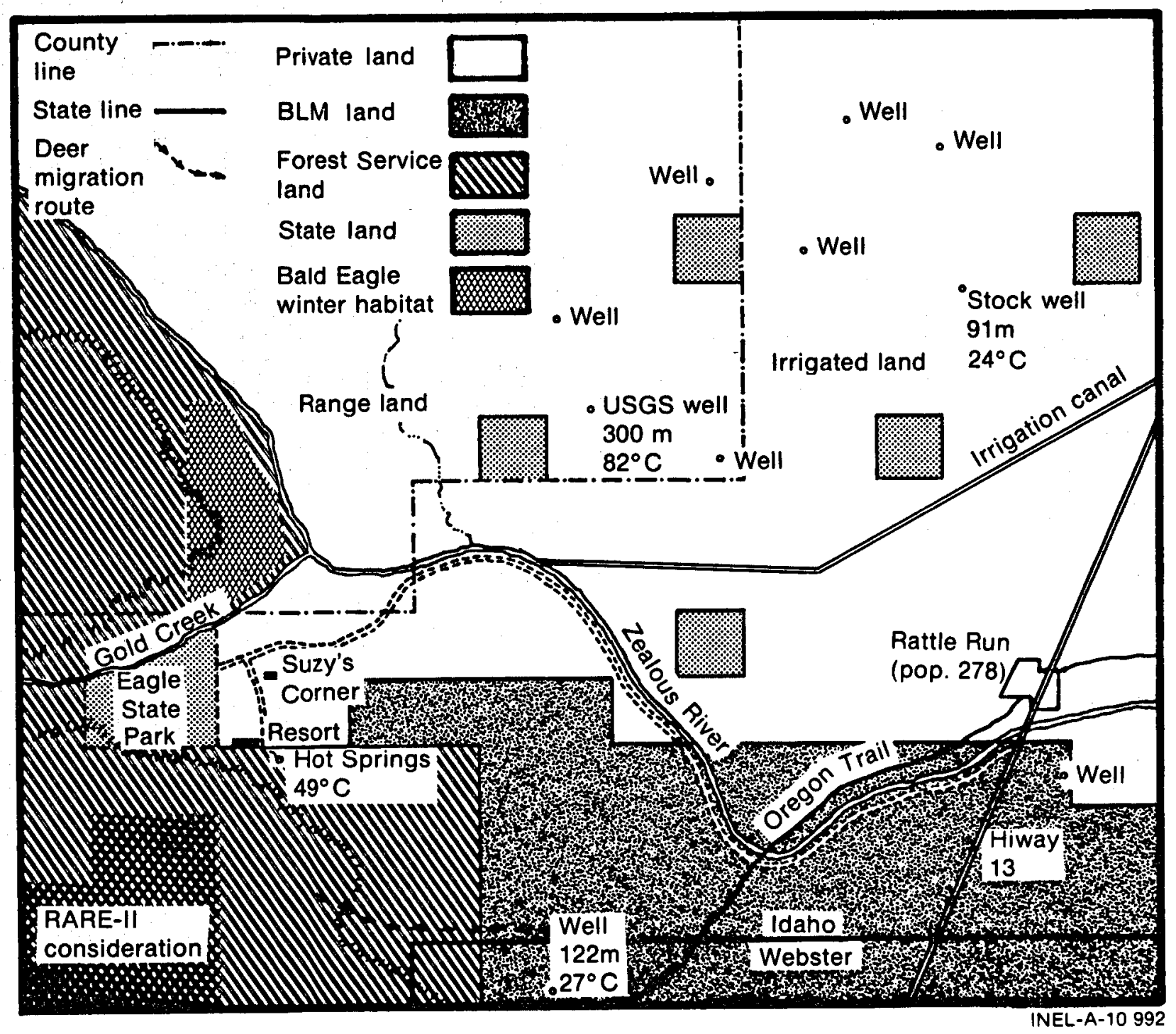

Fig. 19 Simulated environment for resource use exercise. 
(11) non-motorized recreation

(12) archaeological/historical resources

(13) motorized recreation.

Draft environmental data reports have been submitted by the subcontractors. A second workshop scheduled for January 9 and 10,1979, will be technical in nature, with speakers including personnel from regulatory agencies, universities, and consulting firms. Final reports are due from the subcontractors January 30,1979, and will include input from the workshop.

The final project report, prepared by EG\&G Idaho, will be completed by June $1,1979$. 


\section{RELATED PROGRAMS}

During the past year, 11 environmental assessments or reports covering various geothermal activities in Raft River and in the region were issued. These included:

Environmental Report, Raft River Geothermal Pilot Plant, supplement to TREE-1144, November 1977.

Environmental Assessment, Test Hole Drilling at Monroe, Utah, September 1978.

Environmental Assessment, Raft River Geothermal Injection Well \#7 (RRGI-7) and Transfer Pipeline, January 1978.

Environmental Assessment, Raft River Geothermal Injection Well \#6 (RRGI-6) and Transfer Pipeline, December 1977.

Environmental Assessment, Raft River Geothermal Project Transmission Lines, August 1978.

Environmental Report, Raft River Injection Monitor Well System, November 1977.

Preliminary Environmental Assessment, Idaho Geothermal Resource Areas, November 1978.

Environmental Assessment, INEL-1 Exploratory Well, Butte County, Idaho, October 1978.

Environmental Assessment, Geophysical Core Drilling, Idaho National Engineering Laboratory, May 1978.

Environmental Assessment, Geophysical Core Drilling, Sugar City, Idaho, May 1978.

Environmental Assessment, Raft River Heat Flow Holes, September 1978.

No socioeconomic surveys have been conducted since the baseline work was completed in 1976, because of the relatively low level of geothermal activity in the area. As construction on the 5-MW power plant progresses, plans are to conduct research to identify and measure existing and probable impacts of geothermal development on the socioeconomic environment of the Raft River valley. The research will consider likely future trends in key socioeconomic variables, measure the attitudes and perceptions of area 
residents, and relate probable impacts to demands for local government services. Results will be incorporated into local and county planning.

Two site-specific archaeologic surveys were conducted in the area this year. Each area was surveyed on foot at $30-\mathrm{m}$ intervals. No artifacts or chipping detritus were noted at either location, nor were there any historic features or trails evident. These findings are consistent with the findings of previous surveys made at the same general location. 


\section{REFERENCES}

1. S. G. Spencer, N. E. Stanley, W. W. Hickman, Environmental Report, Raft River Thermal Loop Facility, unpublished report available from EG\&G Idaho, Inc.

2. B. E. Lofgen, Land Subsidence and Tectonism, Raft River, Idaho, USGS 75-585 (1975).

3. C. A. Allen and R. E. McAtee, "Tests of Salt Removal from RRGP-5," in G. L. Blake (ed.), Semiannual Progress Report for the Idaho Geothermal Program, April 1 to September 30, 1978, TREE-1 295 (November 1978) pp 13-17.

4. E. H. Walker, L. C. Dutcher, S. O. Decker, K. L. Dyer, The Raft River Basin, Idaho-Utah as of 1966: A Reappraisal of the Water Resources and Effects of Ground Water Development, IDWR 19-1980 (1970).

5. W. L. Niemi and L. B. Nelson, "Injection Testing at RRGI4, Raft River, Idaho," Proceedings of the Second Invitational Well Testing Symposium, Lawrence Berkeley Laboratory, October 24-27, 1978.

6. C. D. Jorgensen, C. M. White, C. L. Pritchett, Raft River Biological Baseline, unpublished report to EG\&G Idaho, Inc. from Brigham Young University (1977).

7. A. Bishop and H. Peterson, Fluoride and Soils in the Raft River Geothermal Area, Utah State University (1976). 


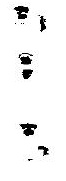

$\checkmark$

7 


\section{APPENDIX}

RAFT RIVER ENVIRONMENTAL INFORMATION REPORTS 


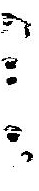




\section{APPENDIX \\ RAFT RIVER ENVIRONMENTAL INFORMATION REPORTS[a]}

A. Bishop and H. Peterson, Fluoride and Soils in the Raft River Geothermal Area, unpublished report to DOE-Idaho Operations Office from Utah State University (1976).

R. Clark, Aquatic Flora of the Raft River, unpublished report to EG\&G Idaho, Inc. from Ricks College (1976).

S. Findholt, Baseline Ecological Data for Geothermal Development in the Raft River Valley, Idaho, unpublished report to DOE-Idaho Operations Office from Idaho State University (1977).

J. A. Goodnight, Community Impact Assessment of a Diversified Geothermal Energy Project Proposed for the Raft River Valley, Idaho, unpublished report to DOE-Idaho Operations Office from Battelle Human Affairs Research Center (1977).

C. D. Jorgensen, C. M. White, C. L. Pritchett, Raft River Environmental Studies, unpublished report to DOE-Idaho Operations Office from Brigham Young University (1977).

C. D. Jorgensen and G. F. Knowlton, Arthropods of the Raft River Geothermal Study Site Area, unpublished report to DOE-Idaho Operations Office from Brigham Young University (1976).

L. H. Kumamoto, Microseismicity Investigation of the Raft River Valley, Idaho, unpublished report to DOE-Idaho Operations Office from Colorado School of Mines (1976).

B. E. Lofgren, Land Subsidence and Tectonism, Raft River, Idaho, USGS 75-585 (1975).

A. G. Morilla and D. R. Ralston, Preliminary Assessment of the Feasibility of Using a Shallow Ground-Water System for the Cooling Cycle of a Geothermal Power Plant, unpublished report to DOE-Idaho Operations Office from University of Idaho (1975).

G. M. Neudorfer, Archaeological Resources of the Southern Raft River Valley, unpublished report to DOE-Idaho Operations Office from Idaho State University (1975).

[a] Available from Biological and Earth Sciences Branch, EG\&G Idaho, Inc., Box 1625, Idaho Falls, ID 83401. 
J. L. Shupe, A. E. Olson, H. B. Peterson, Incidence of Human Dental Fluorosis in the Raft River Area in Southern Idaho, unpublished report to DOE-Idaho Operations Office from Utah State University (1978).

S. G. Spencer, N. E. Stanley, W. W. Hickman, Environmental Report, Raft River Thermal Loop Facility, unpublished report by EG\&G Idaho, Inc. (1977).

R. L. Speth, A Density and Neutron Activation Analysis Study of the Aquatic Invertebrates in the Raft River Near the Geothermal Site, unpublished report to EG\&G Idaho, Inc. from Ricks Cöllege (1976).

R. L. Speth, L. D. Weber, O. D. Simpson, "Trace Element Deposition in Samples Collected from the Raft River Geothermal Site Using Neutron Activation Analysis," Journal of the Idaho Academy of Science, 12 (1976) pp 33-45.

W. O. Ursenbach, W. H. Edwards, J. S. Allan, Baseline Air Quality and Vegetation Studies in the Raft River Valley, 1975-1977, unpublished report to DOE-Idaho Operations Office from University of Utah Research Institute (1978).

Geology and Geophysics of the Southern Raft River Valley Geothermal Area, Idaho, USGS 75-322 (1975).

E. H. Walker, The Raft River Basin, Idaho-Utah as of 1966: A Reappraisal of the Water Resources and Effects of Ground-Water Development, Idaho Department of Water Resources, Bulletin 19 (1970).

C. M. White, T. L. Thurow, J. F. Sullivan, "Siting Criteria as a Function of Sensitivity of Nesting Ferruginous Hawks to Geothermal Development," Proceedings, DOE Control Technology Symposium, Washington, D.C., November 27 to 30, 1978. 
DISTRIBUTION RECORD FOR TREE-1340

Internal Distribution

$$
\begin{aligned}
& 1 \text { - Chicago Patent Group - DOE } \\
& 9800 \text { South Cass } \\
& \text { Argonne, IL } 60439 \\
& 1 \text { - R. L. Blackledge } \\
& \text { Idaho Operations 0ffice - DOE } \\
& \text { Idaho Falls, ID } 83401 \\
& 1 \text { - H. P. Pearson } \\
& \text { Information Processing - EG\&G } \\
& 6 \text { - INEL Technical Library } \\
& 20 \text { - Authors } \\
& 50 \text { - Special Internal }
\end{aligned}
$$

External Distribution

$$
510 \text { - UC-66e - GE: Environmental Research }
$$

Total Copies Printed: 589 